\title{
Selection of Melter Systems for the DOE/Industrial Center for Waste Vitrification Research (U)
}

by

D. F. Bickiord

Westinghouse Savannah River Company

Savannah River Site

Aiken, South Carolina 29808

DOE Contract No. DE-AC09-89SR18035

This paper was prepared in connection with work done under the above contract number with the U.S.

Department of Energy. By acceptance of this paper, the publisher and/or recipient acknowledges the U.S. Government's right to retain a nonexclusive, royalty-free license in and to any copyright covering this paper, along with the right to reproduce and to authorize others to reproduce all or part of the copyrighted paper.

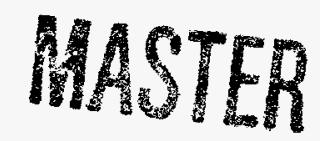


WSRC-TR-93-762

SELECTION OF MELTER SYSTEMS

FOR THE DOE/INDUSTRIAL CENTER

FOR WASTE VITRIFICATION RESEARCH (U)

Dennis F. Bickford,

Advisory Scientist

Westinghouse Savannah River Co.,

Savannah River Technology Center, Aiken, SC 29802.

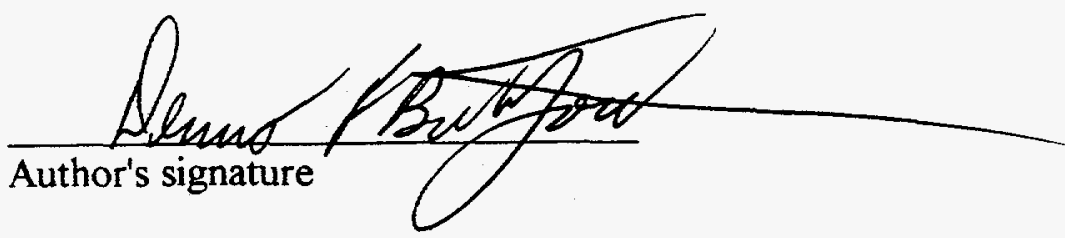




\section{DISCLAIMER}

Portions of this document may be illegible in electronic image products. Images are produced from the best available original document. 


\section{DISCLAIMER}

This report was prepared as an account of work sponsored by an agency of the United States Government. Neither the United States Government nor any agency thereof, nor any of their employees, makes any warranty, express or implied, or assumes any legal liability or responsibility for the accuracy, completeness, or usefulness of any information, apparatus, product, or process disclosed, or represents that its use would not infringe privately owned rights. Reference herein to any specific commercial product, process, or service by trade name, trademark, manufacturer, or otherwise does not necessarily constitute or imply its endorsement, recommendation, or favoring by the United States Government or any agency thereof. The views and opinions of authors expressed herein do not necessarily state or reflect those of the United States Government or any agency thereof.

This report has been reproduced directly from the best available copy.

Available to DOE and DOE contractors from the Office of Scientific and Technical Information, P.O. Box 62, Oak Ridge, TN 37831; prices available from (615) 576-8401.

Available to the public from the National Technical Information Service, U.S. Department of Commerce, 5285 Port Royal Road, Springfield, VA 22161. 
WESTINGHOUSE SAVANNAH RIVER CO. SAVANNAH RIVER TECHNOLOGY CENTER

WSRC-TR-93-762

Keywords: Vitrification, Mixed Waste Integrated Program, MWIP, EM-50, Glass, Low Level Waste, Mixed Waste, TRU Waste, Pu, U, RCRA, TSCA, Hazardous Waste, DOE/Industrial Center for Waste Vitrification, Melter

\author{
SELECTION OF MELTER SYSTEMS \\ FOR THE DOE/INDUSTRIAL CENTER FOR WASTE VITRIEICATION \\ AT CLEMSON UNIVERSITY (U)
}

$12 / 31 / 93$

BY: DENNIS F. BICKFORD

\title{
INTRODUCTION
}

It is important to make the best use of the available technology to aid in the safe and efficient disposal of wastes at the U.S. Department of Energy (DOE) sites. The Mixed Waste Intregrated Program (MWIP), supported by DOE EM-50, seeks to develop and demonstrate technologies which can make significant improvement on existing commercially mature treatment systems. Vitrification has the potential to treat approximately $75 \%$ of the mixed (RCRA hazardous and radioacive) wastes being stored at DOE sites. The waste glass systems that have been previously considered by several DOE sites are soda-lime-silica, borosilicate, aluminosilicate, nepheline, basalt, iron enriched basalt and phosphate glass systems. Glass ceramic systems have also been considered, many of which can be potentially produced as glass and subsequently heat treated to develop crystalline phases. Potential benefits of the application of the existing glass technology to the disposal of Low Level Mixed Waste (LIMW) and low level and mixed transuranic (LIM/TRU) waste types include: well characterized waste form stability and extremely low release rates in a variety of environmental conditions, excellent mechanical and thermal stability, no combustible or pyrophoric properties, retention of essential release properties even if disturbed or mechanically damaged during storage or disposal, low generation of potentially respirable particles, the ability to accept high loadings of heavy metals, ability to accommodate fluctuating waste types with negligable effect on release properties, ability to combust limited amounts of organics (including carcinogens), total 


$$
\text { WSRC-TR-93-762 }
$$

destruction of asbestos, and scale of facility adaptable to accommodate a wide range of disposal needs.

The EPA has designated vitrification as the "Best Developed Available Technology" for immobilization of High-Level Nuclear Waste $\{1\}$. In a recent federal facilities compliance agreement between the ERA, the State of Washington, and the DOE, the DOE agreed to vitrify all of the Low Level Radioactive Waste resulting from processing of High Level Radioactive Waste stored at the Hanford Site. This is expected to result in the requirement of 100 ton per day Low Level Radioactive waste melters. Thus, there is increased need for the rapid adaptation of commercial melter equipment to DOE's needs.

DOE has needed a facility where commercial pilot scale equipment could be operated on surrogate (non-radioactive) simulations of typical DOE waste streams. The DOE/Industry Center for Vitrification Research (Center) was established in 1992 at the clemson University Department of Environmental systems Engineering, Clemson, SC, to address that need. The Center aids in the application of vitrification technology to the immobilization of hazardous, radioactive, and mixed wastes, by combining technology and lessons learned in commercial glass making with DOE contractor experience and DOE needs. During surrogate operations the melters are checked for 1) general operability (i.e. does the unit perform as advertised) 2) general limits of processability (e.g. operating temperature range), 3) normal and specialized maintenance requirements, 4) compatibility with waste glass formulations (i.e. materials of construction, since high temperature equipment can be rapidly destroyed by chemical attack if materials of construction are not suitable) 5) interfaces with the rest of the treatment system (pretreatment requirements, offgas treatment requirements), 6) product conformance to regulatory requirements, and 7) as far as possible the operating economics (Iife cycle costs, manpower requirements, utilities, raw material costs).

Melters selected for the Center could be applied to the immobilization, volume reduction and stabilization of Low level Mixed Wastes (LIMW), Transuranic (TRU), Pu238 (alpha), Low Level, and chemical (RCRA) wastes. Wastes of these types generally do not require heavy shielding to control radiation doses to operating and maintenance personnel. The low penetrating radiation levels of these wastes allow them to be treated in facilities where direct contact maintenance can obviate the expense of remote maintenance facilities. Direct contact maintenance allows the adaptation of commercially available equipment, which was precluded by the restricted maintenance conditions in High Level waste facilities. Thus, rather than using expensive custom melter designs, the processes can potentially use adaptations of commercial glass making equipment. However, these wastes share many contamination and environmental release concerns with High Level waste. Thus, they require similar waste-form quality, contamination control features, 


$$
\text { WSRC-TR-93-762 }
$$

and production control practices as the High-Level Wastes. When treating LLMW the requirements for protection of the operating personnel from contact with the wastes vary dramatically, dependent upon the source and type of the waste. For example, the hazards associated with natural and low enrichment uranium are primarily those of potential heavy metal poisoning. In contrast, the $10-100$ nanocurie per gram low level transuranic wastes are potential sources of ingestion of maximum permissible body burden dosages of plutonium, since they may contain small "hot spots" or particles which could become airbourne and result in assimilations through ingestion or respiration.

This report discusses some of the characteristics of the melter types selected for installation at the Center. An overall objective of the Center has been to provide the broadest possible treatment capability with the minimum number of melter units. Thus, units have been sought which have broad potential application, and which had construction characteristics which would allow their adaptation to various waste compositions, and various operating conditions, including extreme variations in throughput, and widely differing radiologic control requirements.

The ability to obtain generic licensing of the waste form and the process would be very desireable. With generic licensing it is possible to imagine a transportable "melter on a truck" which could be moved between disposal sites, converting commercial wastes on a fee basis. A small SRS melter offgas scrubber system has been installed on a trailer to make it transportable, and has been used in incinerator studies. Such a design could be used in support of a portable melter design to vitrify miscellaneous wastes. A transportable "Modular Melter system" is being procured by SRS for field demonstrations of vitrification at various DOE sites on contact handled wastes. The Modular system will have generic melter feed, offgas treatment and laboratory capacity. Alternative melter systems can be substituted for the original melter after initial operations. A transportable vitrifcation system was developed by westinghouse Electric Co, as was a transportable plasma cupola metal recovery system. A transportable system capable of treating low level wastes with high radiation fields is being developed by Vectra corp.

\section{WASTE TYPES SUITABLE FOR VITRIFICATION}

Vitrification has been demonstrated to be capable of incinerating organic materials and incorporating the resulting ashes in a number of inorganic glass systems. Initial operations of the center have focussed on the vitrification and volume reduction of inorganic sludges resulting from waste water treatment. Parallel efforts under the Minimum Additive Waste Stabilization Program (MAWS), the Buried Waste Integated Program (BWIP) and at other DOE sites are developing treatment of soils and wastes with high metallic content. Mixed 


\section{WSRC-TR-93-762}

wastes at DOE and DOD sites in the geographic region of the Center include those of Table 1. These wastes are typical of those throughout the DOE complex.

Low Level, $\beta-\gamma$ wastes are generally disposed of as cement waste forms, or by deep burial of stabilized waste, because their hazards are similar to those of the uranium ore these wastes originally came from. These wastes result primarily from uranium operations which produce reactor fuel, and targets for plutonium production. At this time, the additional expense of general vitrification relative to cement stabilization is justifiable for simple hazardous or LLW where the volume reduction of the vitrification process can reduce the life cycle disposal cost, or where site specific conditions require the high durability of glass waste forms.

If the Low Level wastes are contaminated with transuranic (TRU) isotopes, have unusually high activities, or contain hazardous chemicals converting them to Mixed Wastes, then the added stability and leach resistance of vitreous waste forms is very desireable, and is generally economically justifiable when transportation and final disposal costs are considered. It is probable that such a disposal method could be most broadly, and cover the broadest categories of waste types, by minimizing the cost of the melter and the raw materials fed to the melter, making its operating costs economically comparable to cement based waste forms. This should be possible through the use of standardized melter designs, and mineral based raw materials, as practiced by the commercial glass industry. Eliminating the use of boron as a glass making additive for these wastes results in an economic trade off that must be evaluated on an individual baisis. Boron reduces the melter operating temperature, making available a broader category of melter materials than those available for soda-lime-silicate glasses. Potential savings resulting from reduced operating and maintenace costs could offset the cost of the boron raw material. Borosilicate glass systems are therefore most likely to be viable for low volume wastes, where the decrease in melt temperature of borosilicate systems allows simplified operations, and use of the same equipment to treat a variety of waste types at a particular site. Economics may be of less concern when the final disposal site is near population centers or regional water supplies. Improved durability would aid in regulatory and public acceptance of the disposal method, and where long lived transuranic isotopes are involved. 


\section{TABLE 1}

\section{Typical Low Level Mixed Wastes at DOE Sites}

Waste Identification

Y-12 soils

K-1407 B\&C

Disposal Area Remedial

Oil Dike 2

Interim Drum Yard

9409-3 Cooling Tower

Civil Center

West End Treatment Fac.

Central Neutralization Fac.

TSCA Incinerator

TSCA Incinerator

ORR Total

M-Area F006

Low Level Alpha

TRU Requiring Treatment

LETF Filter Paper

CIF Blowdown

CIF Bottoms

Suspect solvent

Thirds waste

HEPA Filters

Equipment

Asbestos

$\mathrm{U} / \mathrm{Cr}$ solution

Calcium metal

Soils

Sludges

Scintillation Cocktails

tributylphosphate

n-paraffins

benzene

D\&D wastes

Metals
Location, type

(ORR, S-3 ponds)

(ORR pond sludge/soil)

(ORR, soils)

(ORR, soils)

(ORR, soils)

(ORR, soils)

(ORR,-soils)

(ORR, sludges)

(ORR, sludges)

(ORR, ash)

(ORR, sludges)

(SRS, sludge)

(SRS, drummed job control)

(SRS, drummed mixed solid)

(SRS, Tyvek, sludge)

(SRS, flyash)

(SRS, bottom ash)

(SRS, rags)

(SRS, solid)

(SRS, solid)

(SRS, solid)

(SRS, solid)

(SRS, sludge)

(SRS, pyrophoric)

(SRS, maintenance)

(SRS, remedial ponds)

(SRS, liquid)

(SRS, flammable liquid)

(SRS, flammable liquid)

(SRS, flammable liquid)

(SRS, concrete, soils)

(SRS, solid)
Inventory Contaminants

$\mathrm{kg}$ or $\left\langle\mathrm{M}^{3}\right\rangle$

$$
\begin{array}{r}
300,000 \\
16,000,000 \\
1,300,000 \\
1,300,000 \\
800,000 \\
1,400,000 \\
7,000,000 \\
8,000,000 \\
900,000 \\
100,000 \\
200,000 \\
40,000,000 \\
4,000,000
\end{array}
$$

$<3,730\rangle$

$<3,040>$

$<230>$

$<960 /$ year $>$

$<170 /$ year $>$

$\mathrm{U}$

$\mathrm{U}, \mathrm{Ni}, \mathrm{Ag}, \mathrm{F} 006$

$\mathrm{U}$

$\mathrm{U}$

$\mathrm{U}, \mathrm{Cd}, \mathrm{PCBs}$

$\mathrm{U}, \mathrm{Hg}$

$\mathrm{U}, \mathrm{Hg}, \mathrm{PCB}$ 's

U, phenol, RCRA

$\mathrm{U}, \mathrm{Tc}, \mathrm{RCRA}$

U, RCRA

$\mathrm{U}, \mathrm{Tc}, \mathrm{RCRA}$

U, Ni, F006

$\mathrm{Pu}^{238,239}, \mathrm{~Np}, \mathrm{U}, \mathrm{Pb}$

$\mathrm{Pu}^{238}, \mathrm{~Pb}$

$\mathrm{U}, \mathrm{Ni}, \mathrm{F} 006$

$\mathrm{FP}, \mathrm{U}, \mathrm{Cd}, \mathrm{Pb}, \mathrm{Cr}$

FP, U

$\mathrm{Cs}, \mathrm{Sr}, \mathrm{Cd}$

$\mathrm{Hg}$

$\begin{aligned}<5775 / \text { year }> & \text { FP, Cr, Ni } \\ & \text { RCRA, T, Cs, Sr, TRU } \\ & \text { RCRA solvents } \\ & \text { U, Pu, Np, FP } \\ & \text { U, Pu, TBP, FP } \\ & \mathrm{Cs}, \mathrm{Sr}, \mathrm{FP} \\ & \mathrm{Pb}, \mathrm{Cr}, \mathrm{Ni}\end{aligned}$




$$
\text { WSRC-TR-93-762 }
$$

\section{Mixed wastes, heavy metals, inorganics, asbestos, and organic wastes}

share many of the characteristics of $\beta-\gamma$ wastes, but they contain RCRA listed chemical elements or compounds which require permanent isolation from the environment. The high temperature melting process destroys the chemical compounds associated with such wastes, and ties poisonous elements up into a durable matrix. It has been demonstrated that soda-lime-silicate, alluminosilicate, and borosilicate glasses bind hazardous elements. A model "Upfront" delisting petition is being prepared for SRS M-Area sludge so that these wastes can be delisted from RCRA concern, allowing them to be disposed as Low Level waste. Again, economics plays a major role in the effective disposal of these wastes, the major

justification being that delisting of the hazardous portion of these wastes will allow more efficient disposal. At the same time, it is important to recognize that a large fraction of the wastes falling in this and DOE's Intermediate Level waste category ( $<300 \mathrm{mR} / \mathrm{hr}$ ) originate in TRU and HLW facilities, justifying greater leach resistance than those containing only natural or depleted uranium.

Current SRS wastes of the $\beta-\gamma$ type that are most suitable for vitrification are $M$ Area sludges and filter papers resulting from uranium forming and cladding. The $M$ Area sludges have been contracted for on site vitrification treatment by Duratek Co. There is enough inventory to keep a large scale facility operating for about three years, afterwhich the equipment will be available for treatment of other wastes. In the future, the consolidated Incinerator Facizity (CIF) will produce ash, and offgas filtration residues (blowdown) that will need to be immobilized and stored. Since many of the wastes to be processed in the CIF originate in HLW and TRU facilities, the ashes of the CIF will contain some levels of alpha emmitters, and HLW residues. Current plans are to add cement to bottom ash drums and store the solidified ash in vaults.

Vitrification, with and without waste water treatment, is being investigated for treatment of the blowdown, which has a high salt content. Vitrification is clearly justified for these wastes because it will reduce the waste volume relative to the cement waste form, and will provide an increase in waste form durability: In fact, the vitrification process won over a competitive cementation process for the $M$ Area sludge treatment because it was able to demonstrate lower disposal volumes and costs.

$\alpha$ emitting transuranic wastes (TRU) are comparable to High Level Waste in biologic risk, but require smaller scale operations. In these waste types, major goals are to convert small volumes of liquid or solid flammable wastes into small waste forms that are easy to handle, but provide a high degree of contamination control (isolation). Waste glass is essentially a sealed source, which reduces the dispersibility of a wastes during accidents, and the transferability of activity by contact. The high temperature melting 


$$
\text { WSRC-TR-93-762 }
$$

process combusts organics and reduces the volume of this waste catagory, which primarily consists of contaminated plastic, cloth and paper products. For these reasons, laboratory 1 melters are considered full scale demonstrations for these waste types. Waste loading for these wastes is expected to be controlled by the solubility of fluoride and chloride in the glass. The borosilicate glass system has been evaluated after radiation doses equivalent to 1800 years of a 1 wt\% $\mathrm{Pu}^{239}$ glass, or 620 years of a 0.01 wt\% $\mathrm{Pu}^{238}$ glass, and have shown negligible decreases in aquaeous leach resistance. Numerous borosilicate glasses have been produced with up to 3 wt: $\mathrm{UO}_{2}$, and 0.7 wt: $\mathrm{ThO}_{2}$. SRS has produced glass samples containing 7 wt: $\mathrm{Pu}$, and has demonstrated the necessary feed preparation and offgas system as part of the SRS's Plutonium waste Incinerator Program. Current investigations at SRS include formulation of glasses for vitrifying surplus transuranic solutions. If the TRU solutions were declared waste, they would be considered mixed waste because of their low $\mathrm{pH}$ and high nitrate concentrations. Vitrification will allow the storage and subsequent shipment and use of $\mathrm{Am}$ and $\mathrm{Cm}$. This development program which is being supported by MWIP and SRS operations. Similar operations are being evaluated for $\mathrm{Np}$ and weapons grade $\mathrm{Pu}$, allowing safe storage and appropriate reuse or disposal.

Most of SRS's TRU wastes are expected to be processed in the (future) TRU Waste Facility. Current plans are to repackage and volume reduce these wastes for subsequent disposal in the WIPP Facility. As with HLW, the value of storage space in the WIPP site will be very high, justifying extensive processing to volume reduce the waste, and to stabilize it for shipment and final disposal. Probably the most efficient use of the WIPP site would occur if surface contaminated solids (such as tools and failed equipment) were decontaminated and not put into WIPP. Similarly, the thermal treatment of the remaining material would further reduce the volume. It appears that both graphite arc melting and plasma arc melting are close to demonstrating operating units that could be suitable for such treatment. Doubtlessly, the immobilization of the resulting ash in a glass waste form would be superior to the compacted waste with respect to the safety of transport to the WIPP and the final disposal in the WIPP. It is expected that the $500,000 \mathrm{Ci}$ of $\mathrm{Pu}^{238}$ wastes at SRS will have to be treated before they can be either shipped to, or disposed of at the WIPP. During interim storage at SRS, vitrified ash would be more compact and more stable than compacted waste, reducing diposal cost and improving the safety of storage.

If the nation's inventory of nuclear weapons is to be permanently reduced, then a means of denaturing and disposing of the weapons grade materials (Pu 239 and Enriched U) must be found. Enriched uranium can be blended down with lower enrichment uranium and used for power generation. However, the U.S. does not have a breeder 


$$
\text { WSRC-TR-93-762 }
$$

reactor capable of comparable use of plutonium for fuel. One possible means of controling these materials is to vitrify them in a glass containing neutron poisons, a method endorsed by the National Academy of science. Such a waste form would permit high Pu and $U$ concentrations, allowing inventory verification by calorimetry or radiochemical methods. Pu in such waste forms could be reconverted, but conversion would be slow and difficult making it unlikely that arms control agreements would be violated by reprocessing such materials. Eventually this material could be mixed with fission products to make recovery more difficult, and disposed of in the federal High Level Waste Repository, or other geologic disposal site or engineered storage facility. In this application nuclear criticality control and materials accountability would be major requirements, so a very small melter that is well mixed and totally drained between batches would be appropriate.

Contaminated soils and similar contaminated concrete wastes result from the excavation, repair and decommissioning of Separations, Reactor, and Interim waste storage facilities. Contamination can be the result of hazardous chemical spills, or low levels of TRU or mixed fission products. Currently, these wastes are disposed of without further processing by shallow land burial. Vitrification of these materials will bind the hazardous and radioactive species, reducing the risk of ground water contamination. Examination of in situ vitrification of SRS soils has indicated that the soils require the mixing in of fluxing agents, such as $\mathrm{Na}_{2} \mathrm{O}$ and $\mathrm{CaO}$. Homogeneous addition and mixing is a normal task as a part of the addition of solids to a commercial style melter.

\title{
TECHNICAL REQUIREMENTS FOR THE APPLICATION OF VITRIFICATION TO LOW LEVEL MIXED WASTES
}

\author{
A SRS task team was established to : \\ Determine whether and how SRS's expertise in vitrification \\ technology can be brought to bear on other types of waste. \\ Identify promising candidate waste types for vitrification. \\ Identify research and development programs needed. \\ Identify the resources needed to carry out the programs. \\ Develop a program plan which documents the above activities.
}

The Task Team found that a program for adaptation of HLW vitrification technology to other wastes is clearly needed, and would have a high confidence of making major beneficial impact on the safe and efficient disposal of Mixed and Transuranic wastes at SRS and at other DOE sites (D.F. Bickford, et al, "Application of High Level Waste-Glass Technology to the volume Reduction and Immobilization of TRU, Low Level, and Mixed Wastes". Waste Management '91, pp 537545). The high probability of success is based on the conclusion that, waste forms and equipment of the types necessary have already 


$$
\text { WSRC-TR-93-762 }
$$

been developed, for the most part, during the pilot scale development and testing for HLW immobilization. Equipment is available and can be demonstrated on wastes with comparable chemistries. What is needed is adaptation of equipment and facilities to the particular requirements of handling these other wastes. Relatively low cost and easily repaired melters can now be designed for the economic disposal of TRU and Low Level wastes. Auxiliary systems necessary for integrated melter systems (waste sorting, chopping, feeding, offgas treatment, waste water treatment) and controls have been under development and are directly adaptable from MWIP, HLW, BWID, MAWS, and commercial technology. Non-HLW wastes generally have no or relatively low penetrating radiation levels.

Similarly, the development of the glass waste forms for HLW has investigated a broad range of silicate glass compositions which are adaptable to other waste types. Generalized glass compositions, composition property relationships, and process controls will require minor adaptation from HLW, but obviate the need to develop and qualify new waste forms, and analytical and production control requirements. The borosilicate glass system was selected as the Defense Waste Processing Facility's (DWPE) waste form because of the broad composition variations that are possible while retaining glass durability.

As necessary steps to adapt this technology to other waste types, the Task Team reccommended in decreasing order of priority:

1) A Laboratory Low Level Waste Melter should be installed in a hood, capable of processing depleted uranium. This is required for treatability studies to support the treatment programs. It can serve as the basis for a laboratory sized unit to dispose of miscellaneous mixed and hazardous laboratory wastes.

2) A TRU Waste Glass System should be designed to be integrated with TRU waste handling and treatment systems. This will also provide the operating experience and detailed design required for installation of smaller melters in Pu facilities, so that $\mathrm{Pu}$ wastes can be size reduced, made nonflammable and immobilized before they leave the production facilities. Similar melters could be used to convert excess weapons grade plutonium, neptunium, curium and americium into monolithic forms for storage with reduced risk of criticality accidents, dispersion or diversion.

3) A Mixed Low Level Waste Melter Facility should be created similar to the existing Integrated Demonstration Melter system (IDMS). The IDMS is located too close to the Savannah River to be permitted for actual waste treatment, but a transportable unit could be built for about the same funding that would be required to relocate the IDMS. This unit will provide demonstrations and the necessary operating 
WSRC-TR-93-762

experience for subsequent treatment of Heterogeneous Low Level and Mixed waste incinerator ashes from the Consolidated Incinerator Facility, Oak Ridge TSCA Incinerator, and waste water treatment sludges and soils at various DOE sites. Initial operations could be conducted with joule heated melters adapted from commercial melter systems, with eventual supplementation by a melter capable of processing high metallic content wastes.

4) A Soil Melter System should be developed to convert, at high rates, the contaminated clays, sands and concrete being stored at DOE sites similar to the SRS's Burial Ground and in seepage basins into an inexpensive, high durability waste form for onsite disposal. This melter system could be based on an adaptation of commercial melters.

5) Fused Salt Decontamination Method Development would result in processes that could rapidly remove LIM and transuranic contamination from metallic components. Several salts should be regenerable, with final disposition in waste glass. Demonstration of decontamination efficacy, salt composition, salt regeneration, and vitrification of salt should be demonstrated on glove box scale units.

Subsequent to the task team, the Mixed Waste Integrated Program has outlined more detailed plans for implimentation ( R. Peters, J. Lucerna, M.J. Plodinec, "Vitrification Development Plan for DOE Mixed Wastes, TTP RL332009, April, 1993). The program plan calls for integrated waste form development, processs engineering development, specification development, and integrated pilot scale demonstrations. The MWIP management has added the need for three accelerated field demonstrations on actual wastes by FY 97, in equipment which can be reliably scaled up to full production scale. This has required the aquisition and testing of fully integrated treatment systems in FY 94 and 95 , and increased the emphasis on the adaptation of commercially available, complete treatment systems. DOE orders require that all mixed wastes be treated by 2019 , with specific schedules regulated by the Federal Facilities Compliance Act of 1992, and site specific Federal Facility Compliance Agreements.

\section{AVAILABLE MELTERS AND SYSTEMS}

The Defense Waste Processing Facility (DWPE) at the U.S. Department of Energy's Savannah River Site has an anticipated operating life of over 18 years, using a remotely replaceable melter with a design life of 2 years. Similar equipment and facility development efforts are underway, or have been completed, for HLW disposal at the West Valley Demonstration Project (WVDP), Hanford Waste Vitrification Project (HWVP), and in France, Belgium, the Federal Republic of Germany, and Japan. As part of this process a number of melter systems of various capacities have been designed, constructed and operated. Most of these systems have been operated and maintained in non-radioactive and non-hazardous environments as part of equipment development and 


$$
\text { WSRC-TR-93-762 }
$$

demonstrations. However, several large scale pilot and production units have been operated with hazardous melter feeds, radioactive spikes, or HLW. Design, construction and operation of these facilities provides a basis for the evaluation of the costs of volume reduction and immobilization of other wastes in similar facilities.

An important indication of the waste retention capability of waste glass is a dimensional analysis of the respective waste leach tests used for radioactive waste glass, commercial glass, and hazardous wastes. It can be inferred from this analysis that typical borosilicate waste glass has a durability 1,000 to 100,000 times more durable than that required for the derating of hazardous chemical wastes: Typical waste glass durabilities are comparable to granite, basalt, and other durable rocks. In similar studies, soda-limesilicate glass melters have been demonstrated for the immobilization of glove box wastes. These glasses are expected to have durabilities within a factor of four of those developed for HLW. Thus, it is practical to consider vitrification for converting certain mixed chemical/radioactive wastes into stable radioactive waste forms that do not exceed RCRA criteria. This could have significant impact on the cost of disposing of such wastes, and could also minimize radiation doses that are expected because of certain surveillance procedures necessary for the storage of mixed wastes that would not be necessary for wastes delisted to low level radioactive waste.

Those systems that are currently operable at SRS are listed in Appendix A, with a short description of their capacity. Most of the melter systems available at SRS are the result of HLW vitrification programs, or in support of special processes (e.g. induction melting for reactor fuel and target fabrication). The general operating characteristics of these and commercially available systems are discussed below.

In-Can Melters (Pot Melters) Pot melters using refractory or platinum lined pots are standard commercial methods of melting low volumes of specialty glasses. In-can melters with calciners and slurry fed pot melters were constructed and operated at full scale by PNL and SRS. The original concept for HLW glass melters was for batch operations, which was a direct increase in scale from crucible tests. This approach was found unsuitable for HLW production facilities because of slow melt rates caused by slow heat transfer from the external heaters through the canister into the reacting batch. Lack of agitation and temperature nonuniformities also made it difficult to homogenize the glass. While calcination of feed before introduction into the canister increased the melt rate, it also increased the tendency for crystal formation in the glass, and entrained waste in the calciner offgas system. This method was finally eliminated for U.S. HLW based on the large number of melters, 
calciners and offgas systems (operating in parallel) that would be required to meet the production rates required to dispose of DOE waste inventories. These systems are considered practical for relatively low volume wastes, have simplified maintenance, are easily connectioned between equipment, and have a relatively low capital investment if hardened facilities are not required. Facility cost is dependent upon the hazard of the waste being processed, and can vary between weatherproof sheds to large, remote manipulator cells. The capacity limitations of these systems eliminate them from general consideration, but they remain suitable for small scale operations with LLMW, TRU, and HLW. Glass quality has been maintained in the most recent U.S. systems through rigid control of batch composition. Surrogate operations for such melters can be conducted in ordinary laboratory muffle furnaces with aluminum oxide or kyanite crucibles. This is the standard method of waste glass formulation development.

The in-can melter method remains attractive for small facilities where melt rates are not restrictive, such as At-Line vitrification of $\mathrm{Pu}$ wastes. Subsequent improvements in melter materials and glass compositions permit the slow production of small amounts of waste glass with satisfactory durabilities.

The largest system that was constructed for DOE consisted of a 3 foot diameter composite Inconel 690/ Inconel 625 (TM) tank. That system was dismantled but major components of it are stored at SRS. Early systems had problems in maintaining glass quality because the temperature limitations of the canister material made mixing of the batch difficult. Waste loading is limited by the operating temperature of the pot, which is about $1100{ }^{\circ} \mathrm{C}$ for Inconel (TM) based systems.

The second group of radioactive waste melters developed were continuous pot melters. In this type the melt rate was increased by increasing the diameter of the pot, by direct heating of the pot using radio frequency induction heating, and by continuous feeding of raw materials. Glass homogeneity was improved by using gas bubblers to agitate the melt. The largest melter of this type operating is the Erench AVH system which melts 55 pounds per hour. This is the processing rate limit per pot melter using dried feed: however, with slurry feeding the melter capacity limit would be about one half of this, or 27 pph per melter. The melter design temperature is iimited to about $1150^{\circ} \mathrm{C}$ by creep resistance of the Inconel (TM) alloy used for the pot. Although the use of this system is not practical in high volume programs, this class of melter is modularized, with parts that are relatively easy to replace. An additional benefit of this approach is that only the failed components need be replaced, minimizing the amount of waste generated with melter changeout, and maximizing the useful life of each component. This approach therefore has merit when dealing with homogenous wastes, and where melt rates restrictions are not limiting. For non-homogeneous wastes 


$$
\text { WSRC-TR-93-762 }
$$

the close coupling of the calciner/incinerator function with the melter is not desireable, since it is necessary to classify the calcined waste to remove large metallic pieces. The French AVM and AVH commercial High Level waste systems treat nitric acid based wastes in these systems. The wastes are rotary calcined, combined with premelted glass frit dropped into an induction heated Inconel pot. The systems are reliable, but have relatively low glass throughputs because of the low rates of heat transfer from canister walls through to the unreacted glass batch, the AVH system has added gas bubblers which stir the glass, to improve homogeneity and heat transfer. The Inconel pots are subject to thermomechanical and chemical attack, so they last approximately 2000 hours at temperature.

Similar to the continuous pot melters are the commercially available bushing melters which are used to melt high quality fiber glass. Pots for these systems are fabricated from platinum group metals, and are heated by passing current through the pot. The commercial systems are economically viable because of very low consumption rates of the platinum, and the ability to recover the platinum for reuse. SRS is considering small systems based on commercial bushings for speciallized TRU melting.

Microwave pot melter Microwave heated sytems are being investigated at Rocky Flats Plant and ORNL for treatment of sludges and salts. The RF and ORNL systems use direct microwave heating of the waste, eliminating the need for electrodes in the molten glass. SRS is conducting research at the University of Florida on hybrid sytems, where silicon carbide susceptors provide the microwave coupling required to establish and stabilize the heating. The microwave systems have many of the throughput limitations of the other pot melter systems. Systems which use metal cans as the heating cavity have the glass quality and the waste loading limited by the melting point of the pot. Localized hot spots resulting from nonuniform absorbtion of microwave energy can cause damage to the pot. Metals contained in the waste can result in arcing, which can also damage the pots. Large scale equipment requires tuning systems to maintain coupling at the surface of the melt, reduce the risks to the pot and decrease variations in wasteform quality which can result from nonuniform energy absorbtion. Laboratory scale equipment for crucible testing is very inexpensive, and units have been modified for remote use. Several laboratory scale systems are available at SRS and the University of Florida. HLW analytical samples are typically fused in microwave systems because they permit rapid heating, and only the interior of the chamber becomes hot.

Induction melters have been used for about 40 years at the SRS for production melting of uranium, lithium, plutonium and aluminum alloys, for vacuum hot pressing of plutonium dioxide, and to initiate transuranic fluoride reductions. They are reliable, low cost, high 


$$
\text { WSRC-TR-93-762 }
$$

throughput devices for the melting of metals which directly couple to the radio frequency fields established by the induction coils, or the material to be melted can be indirectly heated by RF coupling to the graphite or silicon carbide crucible. The metal melting systems have used graphite and silicon carbide crucibles, with magnetic stirring to assure alloy uniformity.

Most induction metal melters are tilt-to-pour, exposing operators to molten metal, and fumes. Transuranic systems have been installed in glove boxes to minimize risk. Uranium and lithium systems have relied on localized hoods and exhaust systems for contamination and fume control during charging and pouring.

Commercial induction melter systems are available which can melt in excess of 50 tons per hour of metal at temperaures exceeding $1800^{\circ} \mathrm{C}$. Large commercial systems have limited refractory crucible Iife, which is accommodated by systems which allow spent crucibles to be ejected for disposal, and rapid forming of new crucibles in place in the induction melter using castable ceramic pastes. The Scientific Ecology Group (SEG) has a commercial low level waste operation at Oak Ridge, TN, where contaminated steels are remelted and cast into reactor shielding blocks. The majority of the non-activation product contamination is removed and goes into the flux during the operation. Similar decontamination has been seen in induction melting of stainless steel reactor fuel hulls in France. Reactive metals, such as zirconium are not decontaminated during remelting, because the zirconium is a powerful reducing agent, causing the radioactive species to be chemically reduced and alloyed with the remelted metal.

Commercial melter manufacturers in the United States and France have developed cold crucible induction melters, where the water cooled induction coil is in direct contact with the material being melted. The steep temperature gradients produced adjacent to the induction coil cause a "skull" melting effect, where the material being produced forms its own crucible. In waste melter operations this means that the need for replacement of crucible materials is avoided, at the cost of reduced melting rate. The French are also investigating cold crucible melters with direct $R F$ coupling to waste glass, as a means of achieving high glass melter temperatures without the use of electrodes.

Advanced Gas Melter systems are being developed to provide compact units with high melt rates and minimum operating costs. Similar systems have been investigated as waste incinerators. The systems are based on intimate mixing of the waste and glass forming materials with the fossil fuel providing the operating temperature. The systems have been operated on dry, slurried, and liquid waste streams, and have demonstarted high melt rates. The maximum particle 


$$
\text { WSRC-TR-93-762 }
$$

size of materials to be melted is approximately $2 \mathrm{~mm}$, making them more suitable for finely divided sludges and soils than for coarse soils, concrete or debris. Fundamental questions exist as to: equipment pluggage; Nox behavior; volatility of high vapor pressure metals such as arsenic, cesium, cadmium and lead; volatility of metals which form carbonyls (e.g. nickel); and the physical entrainment and separation of high specific activity materials such as plutonium and cesium. Full chemical balances are required around the melters and offgas treatment systems and are not currently available. Until such fundamental questions are resolved, it is unlikely that these systems can be used for low level wastes resulting form chemical reprocessing of reactor fuels and targets. Once these questions are resolved, the systems could become very important for environmental restoration activites. These systems could not be considered for the center because there are no commercially available laboratory scale units, and testing is being conducted by the vendor on pilot scale equipment.

Slurry Fed Melters (SFM), also known as HLW melters, Joule Heated Melters, and Ceramic Melters, have been developed in the U.S., Europe and Japan for the conversion of HLW to borosilicate glass for permanent disposal. Laboratory and pilot scale operations have been conducted to develop equipment, glass compositions and control methods. The majority of these systems have been developed for remote operation, with essentially no maintenance over a 2 to 4 year melter life. The relatively high cost of these melters is because of the specialized requirements of remote installation, operation, maintenance and removal. The systems were developed for vitrification of waste water treatment sludges, and are very suitable for that operation, but the largest existing design (SRS: DWPF) is limited to about 500 pounds per hour of glass when fed dry feed. Glass composition, melt rate, waste loading and glass quality are limited by the maximum operating temperature of about $1150^{\circ} \mathrm{C}$, resulting from the use of Inconel 690 (TM) electrodes and heaters. Several HLW melters have been operated continuously for over 4 years without requiring repairs.

The slurry fed melters are the result of several generations of melter development based originally on commercial, electrically heated melters, adapted to the requirements of remote, non-contact maintenance, where the only available tools for changing out melter components or entire melters are a crane with hooks and an impact wrench. Major differences between HLW Melters and Commercial Melters have been: the use of metal shells to contain glass contact refractories and thermal insulation, the development of specialized slurry feeding and glass pouring systems, and the use of nickel based alloys for electrodes carefully matched with glass composition control. In this type, the melter is lined with refractory, and the glass is directly heated by conducting electricity through the melt. This system with slurry feeding has been selected for all the HLW 


$$
\text { WSRC-TR-93-762 }
$$

production melter systems in the U.S., Germany and Japan because of high production rate and high glass quality. The size of these systems is effectively limited only by operating facility constraints (e.g. cell space, crane capacity) since all the structural support is provided by a room temperature metal box which contains the refractory. The Inconel 690 (TM) alloy electrodes only need to be self supporting, and high current densities are possible on the faces of the electrodes. Therefore nominal melt temperatures can be as high as $1150^{\circ} \mathrm{C}$, which is only $200^{\circ} \mathrm{C}$ lower than the alloy melting point. Glass production rates are proportional to the surface area of the melt, but convection caused by the joule heating is enhanced as the size of the melter is increased, so larger melters have

proportionately higher melt rates. Small laboratory melters operate below 4.5 pounds per hour per square foot, production melters operate at about 8 pounds per hour per square foot. Melt rates can be doubled by dry feeding. The combination of higher temperature and convective mixing makes the glass very homogeneous.

The major difficulty in slurry-fed ceramic-lined designs is the large number of individual refractory bricks, supporting shell and other components that are required to be assembled to make this type of melter. This complexity increases the melter construction time and installation and disposal costs. In HLW radioactive service, only limited repair is possible, so failure of individual components can require removal and disposal of the entire assembly. Since HLW melters were developed to minimize maintenance, they do not include design features to allow contact maintenance operations such as electrode replacement.

High Temperature Melters are based on commercial melter materials which permit operation at temperatures higher than those of the HLW systems. The commercial systems are also based on direct contact maintenance, allowing cost reductions relative to the HLW systems. As in all high temperature systems, the life of the system, and a large fraction of the cost is limited by the materials of construction. Glass systems include borosilicate, aluminosilicate, calciaaluminosilicate, basalt, and soda-lime-silicate systems. Refractory materials are available in a wide range of operating temperatures, durabilities and cost. Refractory life can be limited by thermal shock, which causes fracture, by dissolution in the melt, or by attack of bottom refractories. Glass refractories are considered acidic, being based on silica, alumina, zirconia, chromia, and other Lewis acids. As a result, most commercial glass systems are susceptible to rapid refractory attack by localized chemical cells if metals accumulate on the bottom of the melter. Commercial melters have been built with graphite, iron, tin oxide, and molybdenum electrodes. Graphite and molybdenum elecrodes can be changed during operation in some of the commercial systems. Electrode life is limited by oxidation, electrochemical attack, and attack by reduced metals, sulfides, arsenic, etc. Electrode life is therefore a 


$$
\text { WSRC-TR-93-762 }
$$

complex function of operating temperature, current desity and glass batch composition. As a result of the broad range of glass compositions and refractory and electrode materials available, a major need for commercial waste glass systems is selection of compositon limits, operating temperatures and materials of construction: For optimum operations these can vary from one waste to the next. A second major need in commercial glass systems is sealing of the systems to control airborne contamination during the melter feeding and glass pouring operations and demonstration of slurry feeding of wet sludges.

Stirred Melter The current stirred-melter was developed to combine the high production rates and high glass quality features of the Joule-heated melters with the low-cost, compact, easily maintained features of the pot melters. Melt rates in the stirred-melter are believed to be proportional to melter volume, rather than melt surface area as in conventional melters. Thus, relatively small scale ups of melter size are expeced to result in disproportionately large increases in the melting capacity. Stir melters can be produced using molybdenum/refractory, graphite, platinum, or all Inconel alloy materials for glass contact. The operating temperatures, melter throughputs, and glass compositions are therefore dependent upon the materials of construction and the size of the unit.

Melt reaction studies, computerized staged reaction models, organic combustion models and melter redox models which are being developed to support the DWPF and Hanford HWVP melters, led to the development of Stirred Melters. Evaluation of the melt reaction sequence indicates that the melter operating temperature need not be as high as the nominal $1150^{\circ} \mathrm{C}$ to assure adequate glass durability. This made possible the consideration of melter designs where Inconel 690 components carry dynamic loads, which is not possible with the nominal HLW operating temperature of $1150^{\circ} \mathrm{C}$.

Several melter design companies were consulted to determine what commercial technology might be applicable. The most promising of these was a proposal by Associated Technical Consultants to develop mechanically stirred melters comparable to those originally

investigated by Owens-IIIinois Company $(O-I)$. This approach offered the possibility of combining the size of the continuous pot melters with the high production rates of Slurry Fed Melters. O-I demonstrated a compact 2 ft cube melt chamber that produced 24,000 pounds per day of partially melted commerical glass from raw materials. It features a simple geometry, with a simple mechanical drive system, and rapid start, drain and restart capabilities. All of these are desirable properties for radioactive service. 


$$
\text { WSRC-TR-93-762 }
$$

However, the existing $O-I$ design did not meet the requirements of radioactive waste disposal because it:

1) required natural gas combustion to start

2) was constructed with electrode and agitator materials chemically incompatible with waste glass feeds

3) produced partially-reacted foam rather than fully-reacted, dense glass

4) could not guarantee that unreacted batch would not be delivered with the final product

5) had restricted electrode surface area

6) used refractory lining, sharing scale up, glass sealing and disposal concerns with the existing ceramic-lined melters

It was determined that necessary characteristics of a practicable agitated waste-glass melter are:

1) adequate durability of glass product

2) all electrical heating

3) use of electrode and agitator materials compatible with oxidizing melts

4) use of alloys with known creep characteristics for predictable melter life

5) maintenance of temperatures and stresses below creep rupture conditions

6) elimination of porosity in product glass

7) stable glass flow with slurry feeding of raw materials

8) self sufficient startup power from resistance heaters

9) vapor space resistance heaters available for melt rate stabilization

10) vapor space temperature above $600^{\circ} \mathrm{C}$ to combust organics

11) ability to drain the tank

12) predictable melter life greater than 6 months.

To minimize glass sealing concerns, and scale up, disposal and repair costs, it is desirable to have all glass contact materials out of one metal alloy rather than a mixture of alloys and refractories. Based on high chromium alloy corrosion studies, waste melter operating experience, and limited creep rupture and creep strength data, it was therefore specified that all glass contact materials be constructed of Inconel 690 (TM) with a maximum operating temperature of $10750^{\circ} \mathrm{C}$. Since this design uses all metal glass contact materials, only 2 melter pieces contact the molten glass. These are the melt tank and the agitator. Replacement of the tank or agitator is possible, minimizing disposal volumes and costs. Thus, this design combines the most desirable features of the continuous pot melters and the slurry-fed ceramic-lined melters. 


$$
\text { WSRC-TR-93-762 }
$$

The measured slurry melt rates with the new design are $155 \mathrm{~kg} \mathrm{~m}^{-2} \mathrm{~h}^{-1}$ with agitation $\left(32 \mathrm{lb} \mathrm{ft}^{-2} \mathrm{~h}^{-1}\right)$, and $19.5 \mathrm{~kg} \mathrm{~m} \mathrm{~h}^{-2} \mathrm{~h}^{-1}\left(4.0 \mathrm{lb} \mathrm{ft}^{-2} \mathrm{~h}^{-}\right.$ 1) without agitation. This demonstrates an increase in the melt rate of a factor of 8, similar to the factor calculated from the OwensIllinois stirred melter tests of commercial glass from raw materials. The demonstrated melt rate was limited by the lack of dispersion of the slurry as it was sheared by the underlying foam. It is estimated that an additional factor of 2 increase is possible before the melt rate is Iimited by electrode current. It is therefore concluded that melt rates of about $290 \mathrm{~kg} \mathrm{~m}^{-2} \mathrm{~h}^{-1}\left(60 \mathrm{lb} \mathrm{ft}^{-2} \mathrm{~h}^{-1}\right)$ are possible through design optimization. Higher melt rates are possible if the materials of construction are changed to molybdenum, graphite, or other high melting point materials.

An Inconel based system with an approximate 3 foot cube internal volume is being installed at SRS to support the Hanford and SRS High Level waste programs. This melter will also be available for surrogate IIMW processing.

Graphite Electrode Arc Melters are the basis for stainless steel and ferro alloy production, as well as such diverse operations as acetylene, phosphate, and fuse-cast refractory production (zirconia, alumina and chromia). Commercial units can be as large as 50 feet in diameter with electrodes in excess of 2 meters in diameter. The electrodes for such systems require constant renewal, since the graphite reacts with the melt and with oxygen in the meiter atmosphere. Methods are available for electrode feeding, including forming and graphitization of the electrodes as they are consummed. Many melters are run "cold top" in open crucibles, where the feed batch provides the furnace cover. Refractories are selected based on the chemical system being processed, and refractory life varies dramatically dependent upon product and the amount of thermal cycling. Most of these systems operate in foundry environments, and have not required sealing of the electrodes to the furnace, or fume control during pouring. As a result, most melter systems have uncontrolled air leakage around electrodes, and do not provide sufficient fume control or prevent contamination of the outside of the vessel. Combustible gasses can be formed by carbothermic reaction, pyrolysis of the treated material or by water-gas-shift reactions between carbon and water. The most extensive research of graphite electrode arc systems for DOE wastes have been conducted under BWIP, by INEL, and by PNL at the Massachusetts Institute off Technology (MIT). MIT tests have focussed on hollow graphite electrodes, allowing the production of coaxial electrodes and the passing of waste materials directly through the plasma, via their addition or exhaust through the hollow electrode. Demonstrations of refractory life, control of melter pouring, control of wasteglass quality, control of combustible offgasses, and control of high vapor pressure metals are required. Bench scale systems have been built 


\section{WSRC-TR-93-762}

and operated sucessfully that include applied glass quality and offgas characterization (P.C. Kong, et al, "Bench Scale Arc Melter for $R$ \& $D$ in Thermal Treatment of Mixed Wastes", EGG-MS-10646, May 1993).

Plasma Arc Melting can be non-transferred or transferred. In the non-transferred arc mode, the plasma torch operates as a very intense heater, with heat transfer occuring via impingement of the arc, or by thermal radiation. In the transferred arc mode, the material being heated forms one of the electrodes, assuring direct heating by the arc, with the possibility of joule heating within the treated material. A portable plasma cupola system is available. Furnaces may be refractory lined, or of the cold crucible type. Refractory lined systems must have control limits to minimize glass and metal attack, and overheating by the plasma. Plasma arc torch design is a mature technology, and is available from a number of vendors, but torches require rebuilding on a monthly basis. Torch failure can result in uncontrolled coolant addition to the treatment furnace. Treatment furnaces have been offered commercially, but except for primary metals production they have been used primarily for recyle of metals or laboratory testing. Systems for tapping and assuring good separation of the metal / glass are under development by the MWIP by SAIC. Demonstrations of refractory life, control of melter pouring, control of wasteglass quality, control of combustible offgasses, control of high vapor pressure metals, control of volatilization and entrainment of radiaoactive materials, integration to offgas systems, and maintenance of the torch under radioactive conditions are required. The non-transfered arc systems are perceived to have superior arc stability and perhaps lower offgas entrainment than the transferred arc systems. The transferred arc systems are expected to be more efficient in maintaining melt pools at temperature, but may require more complicated power and operating systems to assure arc stability and avoid refractory overheating. The Georgia Institute of Technology has been funded by the Department of Defence to develop systems for vitrification of asbestos wastes.

\section{SELECTION OF MELTER SYSTEMS FOR THE DOE/INDUSTRIAI CENTER FOR WASTE VITRIFICATION RESEARCH AT CLEMSON UNIVERSITY}

Available melter systems were evaluated for general adaptability at the center. The evaluation is summarized in Table 2, where systems were considered for Cs wastes, sludges, metals, ashes, debris, soils, and asbestos wastes. This was a subjective evaluation of the current maturity of the systems for the respective wastes, including general design and operating characteristics. The calciner / pot melters are seen as serving a niche where small amounts of extremely hazardous material must be treated, such as weapons grade $\mathrm{Pu}$. The microwave melter systems are not expected to be developed on a scale larger than single-drum treatment systems, and therefore are not likely to be used for high volume wastes. The induction melters are seen as 


\section{WSRC-TR-93-762}

suitable for metallic wastes and drummed wastes, and are probably suitable for asbestos waste where the asbestos is frequently accompanied by metal lath, pipes, etc. The advanced gas melter systems appear to be applicable to liquid wastes, sludges, and soils, if the offgas uncertainties of this technology are resolved and found to result in low entrainment and volatility. The HLW melters were developed for sludges and Cs wastes, but are expected to be less economical to install, operate and maintain than the higher temperature commercial melters. The stirred melter is probably competitive with the high temperature commercial melter for small to medium volume applications. The graphite electrode arc melters seem to be widely applicable to high volume waste streams, where they should be capable of treating sludges, metals, ashes with low volatile metal contents, debris, soils, and asbestos wastes. The plasma arc systems should be capable of treating the same materials as the graphite arc furnaces, but are more likely to cause offgas entrainment of waste and are less mature in refractory selection and metal and glass pouring.

The characteristics of waste-glasses and the attributes required to effectively process and dispose of hazardous wastes are summarized in Tables 3 and 4 . An ideal system was used to consider the relative importance of the various attributes for the major waste categories of 1) low level mixed wastes, inorganics, organics, asbestos and soils, and 2) alpha, TRU, Mixed TRU and Disarmament wastes. The melter types were compared to the ideal system's attributes to assess a figure of merit for the concept. Consideration was given for how close pilot scale operations are to full scale operation with radioactive materials. While the calciner/pot melters were seen as having desirable characteristics, they are perceived as being restricted to very low volumes of wastes. Similarly, the microwave pot melter was seen as being developed to serve the niche of volume reduction, one drum at a time. The induction melter, high temperature commercial melter, graphite electrode arc melter, and the two types of plasma arc melters are seen as being extensively developed with numerous desireable characteristics. The stirred melter or high temperature commecial melter are seen as being capable of treating the same wastes as the HLW melters with reduced cost. The advanced gas melter is seen as a niche melter that is unavailable for testing at the center.

The Center's activities focus on definition of glass process controls, integration of melter systems, and resolution of offgas treatment issues. Given the space limitations of the Center, units have been selected that are compact, and capable of treating a broad variety of wastes. Emphasis was placed on the high volume waste categories: sludges, ashes, and debris / metallic wastes. Where possible, the equipment has been made portable to maximize flexibility in equipment use in outlying years. Vendors were sought who were willing to discount costs, and to actively participate in 


$$
\text { WSRC-TR-93-762 }
$$

the equipment adaptation necessary for radioactive service. FY93 and 94 emphasis has been on the treatment of surrogate waste water treatment sludges from SRS, ORR, RE, and LANL. Final negotiations for procurement, including the negotiation for protection of proprietary rights have been the responsibility, and at the discretion of Clemson University. Clemson operates as a state institution under the laws of South Carolina, and the conditions of the South Carolina University Research and Education Foundation (SCUREF) contract with Westinghouse Savannah River Company. Clemson's decisions for selection of melters was driven by multiple factors, including: melter size, availablity of design and equipent, cost, and expression of interest in cooperative research partnerships on the part of the equipment manufacturers. The two installed systems are the Envitco high temperature commercial melter developed for waste treatment and the StirMelter Co's stirMelter, which was also specifically developed for waste treatment. An induction melter that was used for nonradioactive production at SRS has been obtained for use at Clemson University. A small plasma arc unit suitable for installation at Clemson is also being sought.

Five potential sources of equipment were identified and approached for discussions regarding possible involvement with the center. Each vendor was actively involved in vitrificaation development and demonstration, and was considered a viable player in the developing equipment market.

EnvitCo, Inc., a sister company of Toledo Engineering, Inc., Toledo, $\mathrm{OH}$, was contacted regarding support of the Center's need for high temperature melter capacity. Toledo Engineering has supplied over 400 glass furnaces for sheet and bottle glass manufacturing, with sizes up to 350 tons per day, utilizing both joule heated and gas fired designs. Envitco had manufactured a portable, 2.25 square foot melter for on-site demonstration of hazardous waste vitrification. The configuration of the melter system allowed for one day installation and one day teardown. The melter, as delivered, was designed for cold top operation, but can be operated for short periods in a hot top mode. With minor alterations, the unit can be operated continuously as a hot top design. The melter was available for rapid delivery.

StirMelter, Inc., a subsidiary of Glasstech, Inc., of Toledo, OH, had designed and demonstrated a one square foot stirmelter (TM). This was a prototype design, and had demonstrated its viability on several tests involving simulated HLW slurries, scrap fiberglass recycling, and municipal waste incinerator ash. This design has the flexibility to be configured with an Inconel (TM) melt vessel and agitator bar, or with a ceramic melt vessel and molybdenum impeliers and electrodes. High throughput, and the potential for simplified maintenance made the stirMelter a highly desirable system for demonstration and development in the clemson program. 


\section{WSRC-TR-93-762}

Molten Metal Technology, Inc. (MMT) of Cambridge, MA, had recently designed a laboratory scale melter that was suitable for use by clemson The melter design had the capability of producing slags from inorganic waste streams, and had shown potential for stabilization of LLMW. After a period of discussion around cooperative research involvement and the test program planned by Clemson, MMT withdrew their proposals, stating that they did not want to participate. This is assumed to be an indication that the melter was not ready for the type of testing program that was proposed.

Westinghouse Electric Co., Inc., offered use of a one megawatt portable arc melter that could be made available to Clemson for process development and demonstration. Though the possibilities of use of this melter was attractive, the size, power requirements, and modifications that would be required made this system prohibitive.

South Carolina Research Authority (SCRA) owns two plasma arc melters that were designed in cooperation with MIT for development of high purity chromium smelting. These melters are installed at Charleston, $\mathrm{SC}$, and are available to the program on a rental basis. Due to the proximity of the melters to Clemson and SRS, and the costs associated with transfer and modification of the melters, it was decided that any testing of these melters would be done at the SCRA facility in Charleston.

\section{Facility constraints that limited the selection:}

Melter size was limited by the laboratory space available for the operation. The Rich Environmental Research Laboratory which houses the Clemson Environmental Systems Engineering Department was constructed for typical chemical laboratory research, and was not amenable to the installation of large scale melting equipment, and associated feed and offgas systems. To support the program, a 2000 square foot dedicated laboratory was constructed to house the melters, material handling equipment, offgas systems, and batch storage. All 2000 square feet of the new space was allocated to the program and operations support.

Melter throughput and the melt chamber volume (as related to the amount of waste required to meet steady state conditions) also influenced the melter selection. Under the treatability study exceptions defined in 40CFR 261.4, treatability studies are limited to no more than $1000 \mathrm{~kg}$ of "as received" hazardous waste, with no more than $250 \mathrm{~kg}$ of "as received" hazardous waste being subjected to initiation of treatment in a single day. This limits the size of melter that is feasible for testing, based on both the daily processing limitation, and the amount waste required to establish steady state operation. The EnVitCo melter holds approximately 175 $\mathrm{kg}$ of glass, and processes at rates of $10-20 \mathrm{~kg}$ per hour. These 


$$
\text { WSRC-TR-93-762 }
$$

rolumes and throughput rates require limiting the amount of waste rocessing on a daily basis in order to avoid exceeding the reatability study limitations. The stirmelter requires only about 8 $\mathrm{kg}$ of glass for one melter volume changeover, and operates at $2-4 \mathrm{~kg}$ per hour, easily within the treatability study guidelines.

Availability of the melters was considered, since it was desired to begin testing as rapidly as possible using equipment and processes that were available for use, which could be quickly modified to suit the test program at clemson. Modifications included redesign of the melter chamber refractory to allow for the accumulation and controlled drainage of secondary metals. A hood was also fabricated to allow for offgas collection and control, and permit both cold top and limited hot top operation. All other components ( water/nitrogen distribution and interlocks, power supply) remained unchanged and were immediately available. The Envitco melter was delivered three months after initiation of the project. StirMelter offered the one square foot prototype unit to the project, was but later suggested the construction of a 0.25 square foot melter specifically for the clemson program. This design was brought from concept to construction in three months. A second unit was constructed at the same time, for development at the stirmelter facility. This permitted parallel testing and development, and aided communications and resolution of problems associated with a new design.

Cost considerations were a major driver due to budget constraints, and the concept of cooperative relationships were discussed. Each company had demonstrated good engineering capability, but had limited credibility in the environmental arena. The clemson program offered each partner the opportunity to increase the number of tests done on their equipment, while further evaluating the environmental impact of the process. All testing would be conducted at an independent site. The value of this to potential partners was realized, and resulted in special leasing arrangements.

Acknowlegement: This work was conducted under Contract No. DE-ACO988SR18035 with the US Dept of Energy.

\section{REFERENCES}

An annotated bibliography is attached, including background information and supporting documentation. A summary of the demonstration activities of the center is being developed and will be issued separately. 
Table 1. General Adaptability Determination of Preferred Melter Systems

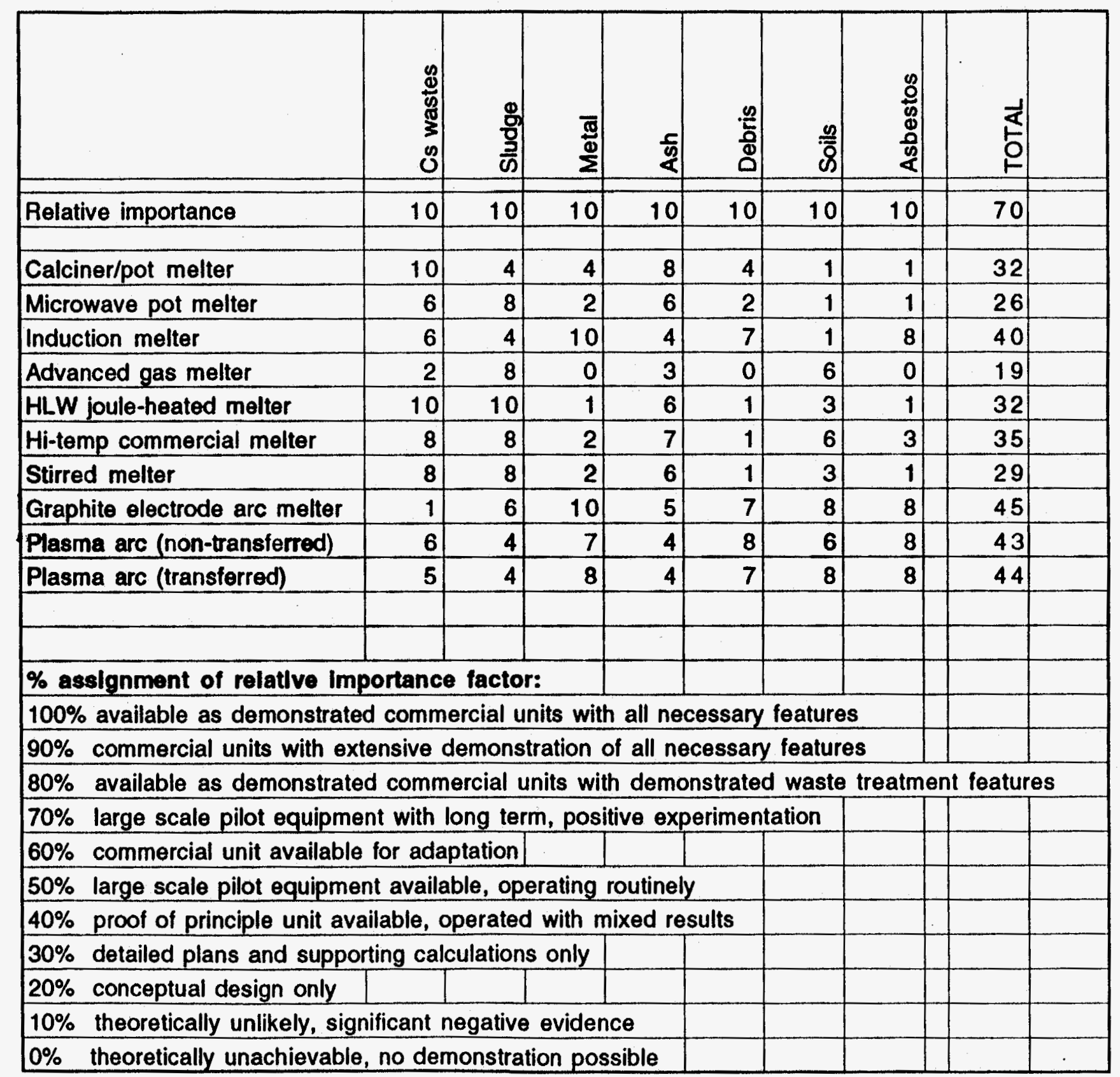


Table 2. Determination of Preferred Melter Systems for Alpha, TRU, Mixed TRU, and TRU Disarmament Treatment

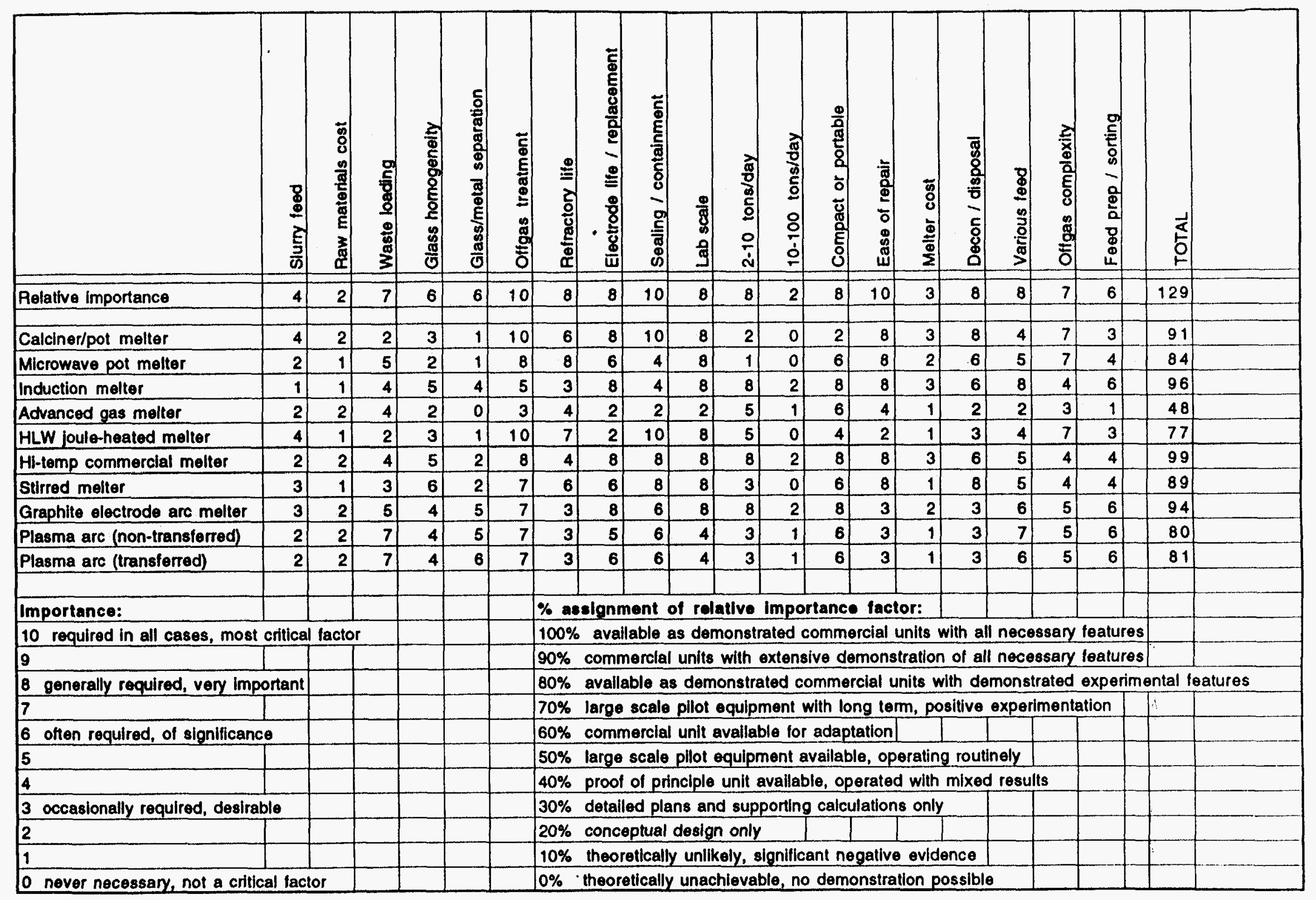


Table 3. Determination of Preferred Melter Systems for LL Mixed Waste, Inorganics, Organics, Asbestos, Soils Waste

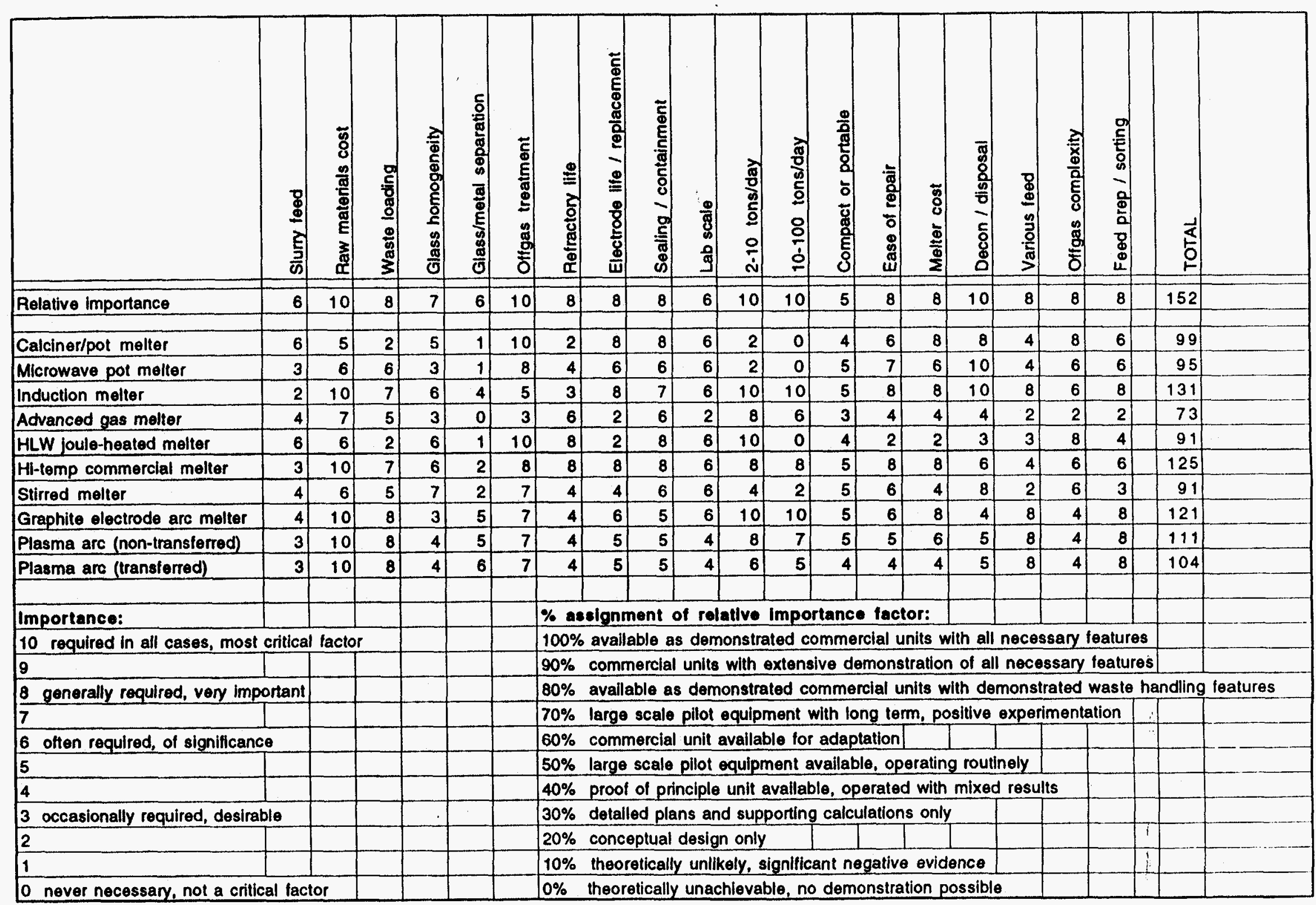




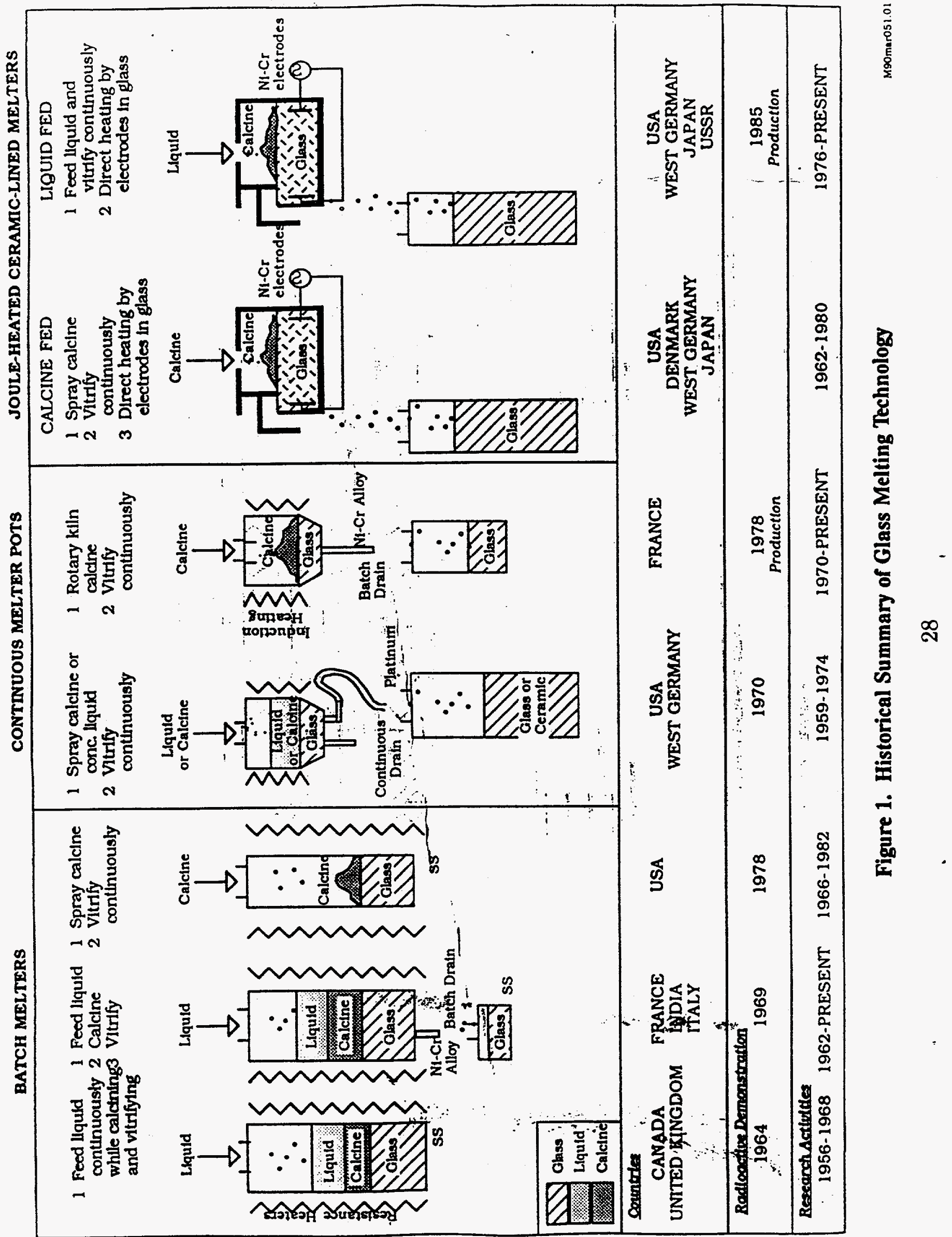




\section{Joule-Heated Research Melter}

Capabilities: $2 \times 70$ Volts $\mathrm{X} 60 \mathrm{Amps}=8.4 \mathrm{kw}$ Maximum Throughput: 2 lb / hour (dry feed (c 50\%)

Versatility:

Installed in chemical hood to permit handling of various toric materials

Full lid heating capacity. Normally used with mercury, silver, lead, selenium, etc. Frequently used for waste solubility, waste form quality, glass redox control measurements. Major changes in batch chemistry are tried here before tests in pilot scale melters. Tilt to pour mechanism.

3 rd generation, 15 years experience, repaired and replaced as necessary.

Offgas system:

Fully scaled down DWPF system:

Ventouri Scrubber, Steam Atomized Scrubber \& Cyclone Condensor \& Demister

Hepa Filtration

Filter Disk and Bubbler scrubbers for special offgas analyses

\section{High Level Caves -- Joule-Heated Research Melter}

Capabilities: $2 \times 70$ Volts $\mathrm{X} 60$ Amps $=8.4 \mathrm{kw}$ Temperature $1150 \mathrm{C}$.

Maximum Waste Tḩroughput: 2 lb / hour (dry feed e 50\%)

Versatility:

Full lid heating capacity. Installed in High Level Cell to permit handling of High Level waste and various toxic materials

Full lid heating capacity. Frequently used for High Level waste verification tests. 3rd generation, 15 years operation, rebuilt and replaced as necessary. Tilt to pour mechanism.

Same facility has capability of leach testing, ICP-AES for elemental analysis, and radiologic testing.

Offgas system:

Ventouri Scrubber, Condensor \& Demister

Hepa Filtration

Eilter Disk \& Bubbler scrubbers for special offgas analyses 


\section{Pilot Scale IDMS Melter system \\ TNX Eacility}

Thermal Capacity Typical $56 \mathrm{kw}$ Temperature $1150 \mathrm{C}$

Throughput 10 pounds waste /hour

Versatility:

A $\$ 16,000,000$ fully integrated melter system duplicating DWPE process. All major feed preparation and offgas scrubbing equipment is run using simialr instrumental controls as the DWPE. Most feed preparation and offgas system components are made of Hastelloy C-276, permitting full flowsheet amounts of corrosive acids, halides, sulfates, etc. Extensive instrumentation of offgas system and feed preparation offgas allows monitoring for $\mathrm{CO}, \mathrm{CO} 2, \mathrm{H} 2, \mathrm{NO}, \mathrm{NO} 2, \mathrm{~N} 2 \mathrm{O}, \mathrm{SO} 2$, and organics.

Normally operates with $\mathrm{Hg}, \mathrm{Ag}, \mathrm{Se}, \mathrm{Cd}, \mathrm{Pb}, \mathrm{Cr}, \mathrm{Cu}, \mathrm{H} 2 \mathrm{SO} 4, \mathrm{HNO}$, etc.

\section{High Temperature Induction Melter}

Equipment: Induction Melter

loaded

Thermal Capacity - typical heatup time I hour fully

Temperature $1900 \mathrm{Ct}$

Throughput $20+$ pounds per hour

Versatility:

Rapid Heating to desired temperature, with maximum temperature about $2000 \mathrm{C}$. Replaceable melt container.

Has been used with Depleted, Natural and Enriched Uranium. Tilt to pour.

Especially applicable for tests where molten steel, stainless steel, iron, etc, are produced. Ideal for metal recycling and reclaimation tests. Temperatures are better controlled than with arc or plasma melting, minimizing volatilization of low boiling point metals, such as cadmium and zinc. Can be fitted with air lance or oxygen lance for oxidation of organics. Has induction stirring for homogenization and improved metal recovery.

Similar unit was used for production of plutonium alloys: design of containment facility available.

Description: Used for induction melting of electrically insulating or conductive materials, and their mixtures. In lab with 2 inch metal shear, and other furnaces operating from 1000 to $1600 \mathrm{C}$. Permitted for low level radioactive testing and hazardous materials. 500 gram enriched uranium limit.

Offgas system: exhauster, double HEPA filtration and stack. Iicensed for use with Low Level Mixed Wastes. 
TITLE: High Temperature Glass Melter

EQUIPMENT: TECO Joule Heated Melter

LOCATION: DOE/Industrial Center for Waste Vitrification Research Clemson SC

CAPABILITIES:

Thermal Capacity $100 \mathrm{kw}$

Temperature $1600 \mathrm{C}+$

Maximum throughput 120 pound/hour

Materials

Treatable Waste - Simulated wastes and Hazardous

Versatility: Especially designed for rapid and inexpensive disassembly and reconfiguration (one week turn around time). Has been modified to permit recovery of molten copper alloys from circuit boards. Will be used to examine alternative electrode materials, and a range of oxidation / reduction conditions.

DESCRIPTION: The melter was especially designed for hazardous waste vitrification by one of the world's largest suppliers of commercial electric melters. The manufacturer can supply similar units with capacities of over 100 tons per day. A high intensity electric field provides locally high temperatures, while maintaining the low pollution characteristics of a cold top melter. Necessary permits are being obtained by Clemson Univ. to operate for Mixed Waste Integrated Program waste simulants.

OEFGAS SYSTEM:

Air dilution

Dry media filter

Reheater and HEPA Filtration

Exhauster and

stack (nonportable)

Wet Scrubber system

Quencher/scrubber

Offgas condensate tank

Atomized Supersonic scrubber and cyclone

Mist eliminator

Supports Mixed Waste Integrated Program.

The offgas system is arranged with the necessary taps for

particulate and gas emission measurements. EPA Method 5 offgas test systems are available.

HPLC, IC, ICP-AES, GC, etc. are available. 


\section{TITLE: Lab Scale Stirred Glass Melter}

EQUIPMENT: $\quad$ Glasstech $1 / 4$ square foot stirred melter......

LOCATION: DOE- Industrial Center for Waste Vitrification Research Clemson SC

\section{CAPABILITIES :}

Thermal Capacity $15 \mathrm{kw}$

Temperature $1100 \mathrm{C}$

Maximum throughput 4 pound/hour

Treatable Waste - Simulated wastes, waste slurries and Hazardous Materials through special arrangements.

\section{Program}

Came on line Feb. 1992. Supports Mixed Waste Integrated

Versatility: Highest throughput per unit size of any joule heated melter. Especially designed for low cost, rapid and inexpensive disassembly and reconfiguration (one week turn around time). Is being used to investigate direct vitrification of wastes under a range of oxidation reduction conditions, and for development of melter sensors.

DESCRIPTION: The melter was especially designed for hazardous waste vitrification in cooperation with SRS. The manufacturer can supply similar units with capacities of over 6 tons per day. Stirring provides exceptionally high melting rates while minimizing the temperature and surface area available for volatilization of waste components. Can be operated batch wize to partially maintain the low pollution characteristics of a cold top melter. Necessary permits are being obtained by Clemson Univ. to operate for SNL and SRS waste simulants.

\section{OFEGAS SYSTEM:}

Dry offgas system avialable. Wet offgas system is being installed.

HPLC, IC, ICP-AES, GC, etc. are available. 
TITLE: Production Scale Stirred Glass Melter

EQUIPMENT: Glasstech 9 square foot stirred melter

LOCATION: Savannah River Site

Aiken, SC

CAPABILITIES :

Thermal Capacity $600 \mathrm{kw}$

Temperature $1100 \mathrm{C}$

Maximum throughput 228 pound/hour slurry

500 pound/hour dry feed

Treatable Waste - Simulated wastes, waste slurries and Hazardous Materials

Comes on line Dec. 1994.

Versatility: Highest throughput per unit size of any joule heated melter. Especially designed for low cost, rapid and inexpensive disassembly and reconfiguration (one month turn around time). Is being used to investigate less expensive and more easily repaired melters for high level waste. Is available part time for non-HLW programs. Will be used for direct vitrification of wastes under a range of oxidation reduction conditions, and for development of melter sensors.

DESCRIPTION: The melter was especially designed for hazardous waste vitrification in cooperation with SRS. The manufacturer can supply similar units with capacities of over 6 tons per day. Stirring provides exceptionally high melting rates while minimizing the temperature and surface area available for volatilization of waste components. Can be operated batch-wise to partially maintain the low pollution characteristics of a cold top melter. Necessary permits are in place to operate for SRS waste simulants, including actual hazardous components.

OFFGAS SYSTEM:

A $\$ 16,000,000$ fully integrated melter system duplicating DWPF process. All major feed preparation and offgas scrubbing equipment is run using simialr instrumental controls as the DWPF. Most feed preparation and offgas system components are made of Hastelloy C-276, permitting full flowsheet amounts of corrosive acids, halides, sulfates, etc. Extensive instrimentation of offgas system and feed preparation offgas allows monitoring for $\mathrm{CO}, \mathrm{CO} 2, \mathrm{H} 2, \mathrm{NO}, \mathrm{NO} 2, \mathrm{~N} 2 \mathrm{O}, \mathrm{SO} 2$, and organics.

Normally operates with $\mathrm{Hg}, \mathrm{Ag}, \mathrm{Se}, \mathrm{Cd}, \mathrm{Pb}, \mathrm{Cr}, \mathrm{Cu}, \mathrm{H} 2 \mathrm{SO}$, HNO3, etc. 
TITLE: Pilot/Production Scale Plasma Arc Melter

EQUIPMENT: $\quad 1.5$ mega watt MIT plasma Arc melter (Carbon Arc)

LOCATION: South Carolina Research Authority

Charleston, SC

CAPABILITIES:

Thermal Capacity $1500 \mathrm{kw}$

Temperature $1600 \mathrm{C}+$

Treatable waste - Simulated wastes, waste slurries and Hazardous Materials

Versatility: Especially designed for low cost operation and reconfiguration (one month turn around time). Is being used to investigate less expensive thermal processing of difficult to melt materials. Can be operated open top, closed top, and with a variety of torch types. A $750 \mathrm{kw}$ unit is also available.

DESCRIPTION: The melter was especially designed for combined metal and slag melting in cooperation with MIT. Can be operated batch-wise or continuous. Necessary permits are in place to operate for waste simulants, including actual hazardous components.

OEFGAS SYSTEM:

A dry offgas system consists of a secondary combuster, offgas cooling, bag house, exhauster and stack.

Normally operates with Cr, As, S etc. 


\section{TITLE: Production Scale Plasma Arc Melter}

EQUIPMENT: 12 mega watt MIT plasma ArC melter

LOCATION: South Carolina Research Authority

Charleston, SC

CAPABILITIES:

Thermal Capacity $12000 \mathrm{kw}$

Temperature $1600 \mathrm{C}+$

Treatable Waste - Simulated wastes, waste slurries and Hazardous Materials

Available July 1993

Versatility: Especially designed for low cost operation and reconfiguration (one month turn around time). Is being used to investigate less expensive thermal processing of difficult to melt materials. Can be operated open top, closed top, and with a variety of torch types. $1500 \mathrm{kw}$ and $750 \mathrm{kw}$ units are also available.

DESCRIPTION: The melter was especially designed for combined metal and slag melting in cooperation with MIT. Can be operated batch-wise or continuous. Necessary permits are in place to operate for waste simulants, including actual hazardous components.

OFFGAS SYSTEM:

A dry offgas system consists of a secondary combuster, offgas cooling, bag house, exhauster and stack.

Normally operates with Cr, As, S etc. 


\title{
TITLE: Lab Scale Rotary Calciner/Melter
}

\section{EQUIPMENT: Custom laboratory Rotary Calciner/Melter}

\author{
LOCATION: Savannah River Site \\ Aiken SC
}

\section{CAPABILITIES:}

Thermal Capacity $3 \mathrm{kw}$ Temperature $1300 \mathrm{C}$ Maximum throughput 0.5 pound/hour Treatable waste - LLMW wastes, waste slurries and Hazardous Materials

Versatility: Very small unit for chemical characterization of waste and offgas. Especially designed for low cost operation and inexpensive disassembly and reconfiguration. It is being used to calcine wastes prior to vitrification in crucibles, and for offgas sampling.

DESCRIPTION: The melter was especially designed for hazardous waste oxidation and vitrification by SRS. It is normally fitted with condensor and vented to hood. Can be fitted with glass pouring, offgas sampling as required.

HPLC, IC, ICP-AES, GC, etc. are available.

\section{WSRC TEST CAPABILITIES:}

Complete waste form development, pilot scale testing and plant design capabilities, including process control meathods and proceedures.

Add Neutron Activation, Microprobe, X-Ray fluorescence, X-Ray Diffraction, HPLC, ICP-Mass Specroscopy, Ion chromotography PCT Test - In final review as ASTM Standard Test Method. 
Annotated Bibliography 
Federal Register, June 1, 1990

Borosilicate glass is declared Best Demonstrated Available Technology

(BDAT) for high level waste

The Evaluation and Selection of Candidate High-Level Waste Forms, DOE/TIC-11611, 1982.

Borosilicate glass selected over alternative wasteforms for Savannah River Site high level waste

Waste Acceptance Preliminary Specifications, OGR/B-8, 1986 (and subsequent revisions)

Preliminary specifications for high level waste production

\section{EM-30 Preliminary Technology Needs List}

Stephen L. Domotor

Treatment; Cost/operating data on available innovative technologies; Develop publicly acceptable incineration technology; Develop thermal treatment technology alternatives to incineration, Plasma reactorsboth high and low temperature

Processes to recover and reuse nitric acid; Cyanide treatment; Nitrate treatment; Ferrocyanide treatment; Separation techniques for removing RCRA listed inorganics from non-RCRA listed matrices; Destruction or removal of RCRA listed wastes from mixed waste; Actinide conversion technology

Waste Form and Packaging; ${ }^{90 \mathrm{Sr}}$ and ${ }^{137} \mathrm{Cs}$ waste forms, $99 \mathrm{Tc}$ and $129 \mathrm{I}$ waste forms; Borosilicate glass and ceramic or glass ceramic HLW waste form formulations; Waste loading vs. performance criteria for HLW waste forms; Fluorite-based oxide waste forms for TRU; Phosphate-based ceramic waste form for TRU; Reuse of decontaminated material for waste form packaging

Storage and Disposal; Valid risk assessment procedures; extention of storage lifetimes

Vitrification Development Plan for DOE Mixed Wastes

Richard Peters, Joe Lucerna, M. John Plodinec

Waste Site Activities - Rough Screening; Vitrification Development; Waste Form Development; Process Engineering Development; Specifications for Treatment Processes; Integrated Pilot Scale Demonstration

\section{Mixed Waste Integrated Program}

J. B. Berry

IDC/IPC Coordination Meeting, July 13-14, 1993

Qualify new, emerging, and existing technologies on a systems basis; Demonstrate complete and appropriate technologies

Assessment and feasibility of enhanced waste forms; Developing improved or alternative technologies for EM-30's prototypical Mixed Waste Treatment Plant; Developing improved or alternative technologies for EM-30 site specific mixed waste plans; Developing improved or alternative technologies for small volume, problematic mixed wastes 


\section{Mixed Waste Integrated Program Peer Review}

Richard Peters

Battelle, Pacific Northwest Laboratory, June 1993

Development of enhanced final waste forms; treatment for delisting of mixed wastes; vitrification processing; develop and characterize glasses; demonstrate vitrification processing; transfer the results to industry

Most mixed waste is amenable to vitrification; leach-resistant glasses can be formulated; electric glass melter reliable, low-maintenance, and cost effective; quality is inherent in process if joule-heated

Literature Search

Processing of Transuranic Waste Waste at the Savannah River Plant B. A. Daugherty, L. M. Salizzoni, S. J. Mentrup

Spectrum '86, pp. 1779-1786

Stored primarily in 55-gallon drums and large carbon steel boxes

\section{Final Waste Form - Vitrification}

Richard D. Peters

Pacific Northwest Laboratories, PNL Support FY 1993

Vitrification Development Plan; Glass Melt Studies using Surrogates; Vitrification Process Limitations

Data Needs - Waste Characterization: physical form, physical properties, rough size distribution, primary metal content, volatile metal content, metal cation/oxide content, water content, combustibles content, hazardous organic compound content, anion content, radiochemical analysis, radiation field

Data Needs - Waste Form Development/Treatability Studies: waste glass composition, glass formers/additives, effect of compositional variability, viscosity, electrical conductivity, metal retention in glass melt, TCLP of glasses, leaching characteristics of glasses, metals drop-out in crucible melts, melting temperature, homogeneity, phase separation, foaming tendency

Data Needs - Process and Engineering Development: feed composition, time to steady state, volatility of feed materials, off-gas flow; off-gas temperature, off-gas solids loading

Data Needs - Integrated Pilot Plant Testing: off-gas analysis, processing rate, glass quality, maintenance requirements, equipment performance, dynamic system responses: power, feed rate, inlet air...

\section{Solid Waste Management Plan (Predecisional Draft)}

B. A. Daugherty

Savannah River Site, November 29, 1993

Low Level Mixed Waste: CIF Blowdown Stabilization Alternatives; PVC Alternative Plastics; Re-evaluate Vault Concept for Disposal;

Evaluation of Sending CIF Ash to E-Area Vaults

Identify waste streams generated from ER and D\&D

Design and Planning for TRU Retrieval; Provide strategy for interim storage;

Proceed with technology for TRU waste treatment 
Hazardous Waste: $90,000 \mathrm{cu}$. $\mathrm{ft}$.

Mixed Waste: $70,000 \mathrm{cu}$. $\mathrm{ft}$.

Low Level Waste: $2,500,000 \mathrm{cu} . \mathrm{ft}$.

TRU Waste: $400,000 \mathrm{cu}$. ft.

Opportunities for Vitrification: Centralized facility for potential stabilization of numerous streams; Other mixed wastes as identified in conjunction with the site treatment plan, national program direction, and the vendor proposal program; <100 NCi TRU mixed wastes; High activity TRU wastes (PU-238)

Precisional Draft Vitrification of Excess Plutonium, WSRC-RP-93-755 J. M. McKibben, et al.

Westinghouse Savannah River Company, May 1993

$\mathrm{Pu}$ from dismantled nuclear weapons and other sources; three major options: storing the plutonium, using the plutonium in fuel for nuclear reactors, vitrifying the plutonium in borosilicate glass, with or without the addition of high-level waste

Assess the state of technologies for vitrifying plutonium in borosilicate glass (with or without added radioactivity); capabilities to perform this mission, and abililty to transport these technolgoies to other locations in the United States and in other countries

Steps from initial receipt to final disposition: preparation, conversion, vitrification, storage, terminal disposition

Vitrification: Small Melter Vitrification, Large Melter Vitrification

Generic Considerations: Glovebox Systems, Plutonium Loading, Operational and Public Safety, Criticality, Materials Control and Accountability, Safeguards, Waste

Applicable SRS Facilities; Timing; Costs

Generic Flowsheets; Criticality Calculations-Values of $\mathrm{K} \omega$ for Solid Glass; Simulating Flooded Pu-Glass Frits

Westinghouse Savannah River Company, Special Consolidated Solicitation No. E10600-E1; A Statement of SRS Waste Processing Needs

Westinghouse Savannah River Company, August 31, 1993

Treatment of Silver Coated Packing Material; Treatment of Cadmium-Coated HEPA Filters; Low-level Waste Lead; ITP Filters; Poisoned Catalyst Material; Alpha Contaminated Waste $<100 \mathrm{nCi} / \mathrm{g}$ (SW-08); Uranium/Chromium Solution; Calcium Metal; Radioactive Oil; TriButyl-Phosphate and N-Paraffin; Waste Site/Spill Site Soil; Tank E-3-1 Clean Out Material; ITP Samples; Spent Filter Cartridges; Cadmium Contaminated Glovebox Section; Enriched Uranium Contaminated with Lead; Filter Paper Take Up Rolls in Cardboard Boxes; Mark 15 Filter Paper in Cardboard Boxes; Low-Level Waste Compaction; Drum Retrieval; Drum Venting; TRU Waste Repackaging and Certification; Automated Drum Handling; TRU Contaminated Waste Drying; Drum Decontamination; Radioactive Inventory and Characterization of Waste Container Contents; Asbestos from Process Area HVAC System; 
Clearance and Tratment of Suspect Soil, up to $400,000 \mathrm{cu}$. ft./year; Reactor Moderator Deionizer Resins Treatment and Disposal

Soils Contaminated with Metals/Radionuclides/Solvents, 60 basins or pits at SRS, metals, radionuclides or solvents; Soils Contaminated with Fuel Hydrocarbons; Sampling Techniques for High Activity Waste; Waste Retrieval/Recovery Technology

Off-gas Treatment Needs; Robust Techniques for Sampling and Analyzing Gas Streams for HCl; Plasma arc melter capable of treating drummed wastes, sludges, and other debris; Portable demonstration facilities with offgas treatment, melters, and analytical instrumentation for melter feed and product analyses; Small melters for transuranic wastes, capable of being installed in glove box facilities; Equipment for rapid determination of waste composition and glass product quality; Advanced process control programs

Standardized Surrogate Waste Streams

John Mayberry, Memo, February 23, 1993

SAIC

Generic Compositions for Testing

Surrogate Formulations for Thermal Treatment of Low-Level Mixed Waste: Part I: Radiological Surrogates (Draft) (DOE/MWIP-15, September 29, 1993)

J. A. D. Stockdate, W. D. Bostick, D. P. Hoffman

Martin Marietta Energy Systems, Inc.

Surrogates for ${ }^{99} \mathrm{Tc}$; Surrogates for ${ }^{239} \mathrm{Pu}$; Surrogates for Uranium;

Surrogate Recommendations

\begin{tabular}{ll} 
Radioisotope & Surrogate \\
\hline $238 \mathrm{U}, 235 \mathrm{U}$ & $\mathrm{Ce}$ \\
${ }^{99} \mathrm{Tc}$ & $\mathrm{Ru}$ \\
${ }^{137} \mathrm{Cs}$ & $\mathrm{Cs}$ \\
${ }^{90 \mathrm{Sr}}$ & $\mathrm{Sr}$ \\
${ }^{239 \mathrm{Pu}}$ & $\mathrm{Ce}$ \\
$103 \mathrm{Ru}$ & $\mathrm{Ru}$
\end{tabular}

Surrogate Formulations for Thermal Treatment of Low-Level Mixed Waste: Part II: Selected Mixed Waste Treatment Project Waste Streams (Draft) (DOE/MWIP-16, September 30, 1993)

W. D. Bostick, D. P. Hoffman, J. M. Chiang, W. H. Hermes, L. V. Gibson, Jr., A. Richmond, J. Mayberry

Martin Marietta Energy Systems, Inc.

Surrogates Formulation; Neutral aqueous wastes; Aqueous halogenated organic liquids; Ash; Absorbed aqueous and organic liquids; High organic content sludges; Cement sludges, ashes, and solids; Chloride, sulfate, and nitrate salts; Heterogenous debris; Lab packs; Lead shapes

Hazardous Organics and Potential Surrogates; EPA 40 CFR 261 Thermal Stability Glasses 
Surrogate Formulations for Thermal Treatment of Low-Level Mixed Waste: Part III: Plasma Hearth Process Testing (Draft) (DOE/MWIP.17, September 29, 1993)

J. M. Chiang, W. D. Bostick, D. P. Hoffman, W. H. Hermes, L. V. Gibson, Jr., A. Richmond Martin Marietta Energy Systems, Inc.

Surrogate Selection Rationale: Radiological Wastes, Organic Wastes, RCRA Metals, Bulk Component Selection, Limitation of Surrogate Application

Waste Surrogate Recipes for Plasma Hearth Process: Inorganic Sludge, Organic Sludge, Bulk Combustible

$590,000 \mathrm{~m}^{3}$ of mixed wastes, $247,000 \mathrm{~m}^{3}$ is reported to be that of low level mixed wastes; additional $298,000 \mathrm{~m}^{3}$ of mixed wastes estimated to be generated during next five years

LLMW, approximately 79\%, stored Rocky Flats Plant (RFP), Oak Ridge K-25 Site, Idaho National Engineering Laboratory (INEL)

Land Disposal Restriction (LDR)

Cerium compounds, conservative surrogates for both $\mathrm{U}$ and $\mathrm{Pu}$; natural $\mathrm{Cs}$ nonradioactive marker for the relatively volatile fission products

Table 1. Suggested Surrogates for Selected Radioisotopes

Suggested Surrogate(s)

Radioisotope

U-238/U-235

$\mathrm{Pu}-239 / \mathrm{TRU} \mathrm{U}^{2}$

Tc-99, Ru-103

Cs-137

Sr-90

${ }_{1 \mathrm{RE}}=$ rare earth element (lanthanide series)

2TRU = transuranium element (e.g. Np Am, etc.)

Inorganic Sludge: Perlite, $\mathrm{Fe}_{2} \mathrm{O}_{3}, \mathrm{CaSO}_{4}, \mathrm{Al}_{2} \mathrm{O}_{3}, \mathrm{NaNO}_{3}, \mathrm{MgO}, \mathrm{Cr}, \mathrm{Ni}, \mathrm{Pb}$, $\mathrm{Cd}$, Naphthalene, 1,2-Dichlorobenzene, $\mathrm{Ce}_{2} \mathrm{O}_{3}, \mathrm{CsCl}$

Organic Sludge: Activated carbon, cation exchange resin, cellulose, $\mathrm{Na}_{2} \mathrm{SO}_{4}$, $\mathrm{CaCO}_{3}, \mathrm{Cr}, \mathrm{Ni}, \mathrm{Pb}, \mathrm{Cd}$, Naphthalene, 1,2-Dichlorobenzene, $\mathrm{Ce}_{2} \mathrm{O}_{3}$, $\mathrm{CsCl}$

Bulk Combustible: Activated carbon, cation exchange resin, cellulose, wood chips, paper, cloth, polyvinylchloride, polyethylene, rubber (neoprene), $\mathrm{Cr}, \mathrm{Ni}, \mathrm{Pb}, \mathrm{Cd}$, Naphthalene, 1,2-Dichlorobenzene, $\mathrm{Ce}_{2} \mathrm{O}_{3}, \mathrm{CsCl}$

Surrogate Formulations for Thermal Treatment of Low-Level Mixed Waste: Part IV - Waste Water Treatment Sludges (Draft) (DOE/MWIP-18, September 29, 1993)

W. D. Bostick, D. P. Hoffman, R. J. Stevenson, A. Richmond, D. F. Bickford Martin Marietta Energy Systems, Inc.

Y-12 Plant West End Treatment Facility Sludge, Rocky Flats Plant By-Pass Sludge; Los Alamos National Laboratory Dewatered Treatment Sludge; Oak Ridge K-25 Site Pond Waste Sludge

WETF nitrate-containing wastes by biodenitrification, neutralized with lime mixed with nutrients, bioreactor anoxic denitrification 
500,000-gal. tanks F-7, F-8, F-9, F-13; 7,100 m³ RCRA waste codes F001, F002, F005, F006

Dry Mix Blend: $\mathrm{Al}(\mathrm{OH})_{3}, \mathrm{Fe}_{2} \mathrm{O}_{3}, \mathrm{NaHCO}_{3}, \mathrm{CaCO}_{3}, \mathrm{MgCO}_{3}, \mathrm{BA}(\mathrm{OH})_{2}$, dry yeast powder

Metals Spike Solution: $\mathrm{Cr}, \mathrm{Cd}, \mathrm{Cu}, \mathrm{Pb}, \mathrm{Ni}, \mathrm{RAD}, \mathrm{UO}_{2}$ or $\mathrm{Na}_{3} \mathrm{MO}_{4}$ or $\mathrm{Ce}_{2} \mathrm{O}_{3}$ or $\mathrm{CeO}_{2} ; 0.1 \mathrm{~N} \mathrm{HC} 1$

Rocky Flats Plant By-Pass Sludge: process sludge slurries concentrated through a rotary drum vacuum filter, precoated with diatomaceous earth filter media; water content of up to $60 \% ; 0.5 \mathrm{Kg}$ of Portland cement/diatomaceous earch (DE) blend (1:1) to each 55-gal. drum of sludge (about $600 \mathrm{Kg}$ ) to control free water; some waste packages were solidified with approximately $30 \%$ Portland cement

TRU waste

Simulated RFP Sludges: $\mathrm{Al}_{2} \mathrm{O}_{3}, \mathrm{NaOH}, \mathrm{CaO}, \mathrm{CaSO}_{4}, \mathrm{Na}_{3} \mathrm{PO}_{4}, \mathrm{MgO}$, $\mathrm{Mg}(\mathrm{OH})_{2}, \mathrm{~K}_{2} \mathrm{CO}_{3}, \mathrm{Fe}_{2} \mathrm{O}_{3}, \mathrm{FE}(\mathrm{OH})_{3}, \mathrm{NaNO}_{3}$, Diatomite

Los Alamos National Laboratory Dewatered Treatment Sludge: diatomaceous earth, perlite; annual generation $250 \times 55$-gal. drums; current inventory $270 \mathrm{~m}^{3} ; 139 \mathrm{~m}^{3}$ subject to EPA LDR prohibition

RCRA waste codes F001, F002, F005A; one occurrence for Cd exceeding TCLP limits

Formulation of Simulated LANL Sludge Solids: Perlite, $\mathrm{CaCO}_{3}, \mathrm{Fe}_{2} \mathrm{O}_{3}$, $\mathrm{Al}_{2} \mathrm{O}_{3}, \mathrm{MgO}, \mathrm{Ce}_{2} \mathrm{O}_{3}$

Oak Ridge K-25 Site Pond Waste Sludge: 32,000 drums (89 and 96-gal. capacities); 46,000 drums of stabilized sludge; current inventory 26,500 $\mathrm{m}^{3}$; EPA-listed F006 waste

Simulated Pond Waste Bulk Constituents: $\mathrm{H}_{3} \mathrm{PO}_{4}, \mathrm{NaCl}, \mathrm{NaF}, \mathrm{NaHCO}_{3}$, $\mathrm{K}_{2} \mathrm{CO}_{3}, \mathrm{Na}_{2} \mathrm{SO}_{4}, \mathrm{MgO}, \mathrm{Fe}_{2} \mathrm{O}_{3}, \mathrm{Al}(\mathrm{OH})_{3}, \mathrm{CaCO}_{3}$, clay

Ash Analysis Results (SRT-WHM-93-005)

D. L. Fisher

Savannah River Technology Center, 1993

Consolidated Incinerator Ash Composition

Oak Ridge National Laboratory West End Treatment Facility Simulated Sludge Vitrification Demonstration (WSRC-RP-93-1111)

C. A. Cicero, D. F. Bickford, D. M. Bennert, T. J. Overcamp

WSRC/CU, 1993

Task Discussion; ORNL WETF Waste Description, Melter Systems; Melter Feed, Surrogate, Glass Forming Additive, Test Strategy; Quality Assurance; Documentation; Responsibilities

Hydrous borax and diatomaceous earth will be used as the glass forming additives

Rocky Flats Plant Precipitate Sludge Surrogate Vitrification Demonstration (WSRC-RP-93-Draft)

C. A. Cicero, D. F. Bickford, D. M. Bennert, T. J. Overcamp

WSRC/CU, 1993 
Task Discussion; RFP Precipitate Sludge Description, Description Melter System; Melter Feed, Surrogate, Glass Forming Additive, Test Strategy; Quality Assurance; Documentation; Responsibilities

Hydrous borax and diatomaceous earth will be used as the glass forming additives

Los Alamos National Laboratory Simulated Sludge Vitrification Demonstration (WSRC-RP-93-Draft)

C. A. Cicero, D. F. Bickford, D. M. Bennert, T. J. Overcamp

WSRC/CU, 1993

Task Discussion; LANL Waste Description, Melter Systems; Melter Feed, Surrogate, Glass Forming Additive, Test Strategy; Quality Assurance; Documentation; Responsibilities

Hydrous borax and diatomaceous earth will be used as the glass forming additives

\section{Glass Furnaces Design Construction and Operation}

Wolfgang Trier

Society of Glass Technology, 1987

Technical criteria, description of designs; Construction elements and dimensions; Selection and use of refractories in glass furnaces; Operation of glass tank furnaces; Mathematical models of glass tank furnaces; Electric tank furnaces; Transfer of energy from electrodes to molten glass, Electrode circuits; Electrode materials: Molybdenum, Graphite, Tin oxide, Platinum. Day tanks; Pot furnaces; Fuels and combustion; Emissions from glass furnaces

\section{Advanced Radioactive Waste-Glass Melters}

Dennis F. Bickford

Nuclear Waste Management IV, American Ceramic Society, pp. 335-347

Need for continued melter design development to support DWPF; wastes that are water soluble or a dispersible slurry; Transuranic (TRU), $\mathbf{P u}^{238}$, uranium, chemical (RCRA) wastes, mixed radioactive/chemical wastes (mixed wastes)

New melter design combines the high production rate of large ceramic lined melters with the low cost, simplified construction, and simplified disposal of pot melters

Vitrification of Mixed Wastes: Establishment of DOE/Industry Center for Waste Vitrification Research

Dennis F. Bickford

SRTC Progress Report, November 6, 1992

Small Pilot Scale Vitrification of Simulated DOE Waste; Proof Test Commercial Equipment; Resolve Effluent and Mass Balance Issues; Generic Response to Regulatory Agencies

Contamination Control Features; Long Duration Tests, Engineering Features, Integrated Process Controls

Cooperative process and equipment improvement; Protection of Proprietary Rights 
Pilot Scale Vitrification Laboratory for Treatability Studies on Hazardous and Mixed Wastes

D. M. Bennert, T. J. Overcamp. T. N. Sargent, Jr., J. L. Resce, D. F. Bickford WSRC/CU, 1993

Facilities and Melting Capabilities:

EnVitCo EV-16 refractory lined, water cooled $0.16 \mathrm{~m}^{2}$, 'cold top' method to reduce metal volatility; $1500^{\circ} \mathrm{C}$ in the molten glass, $200^{\circ} \mathrm{C}$ on the top of the batch

Stir-Melter, Inc., $0.022 \mathrm{~m}^{2}\left(0.007 \mathrm{~m}^{3}\right) ; 610$ impeller, vessel; high mixing rates permit rapid incorporation of the batch materials into the melt

Pilot Scale Vitrification Studies on Hazardous and Mixed Wastes

D. M. Bennert, T. J. Overcamp, K. L. Compton, T. N. Sargent, Jr., J. L. Resce,

D. F. Bickford

Proceedings of the Second International Symposium on Mixed Waste,

Baltimore, MD, August 17-20, 1993, pp. 4.3.1-4.3.9

Clemson University in cooperation with Westinghouse Savannah River

Company, EnVitCo., Inc., and Stir-Melter established a center for pilot scale waste vitrification research; conduct vitrification feasibility studies; environmental impact studies

Characterization of the untreated wastes and residual glasses; TCLP; Offgas studies for the degree of organic combustion, particle emissions, metal volatility, and semi-volatile organic emissions

\section{Regulatory Issues in Vitrificaiton Research: A Case Study of Circuit} Board Reclamation

K. L. Compton, D. M. Bennert, D. F. Bickford

Amercian Ceramic Society Annual Meeting, Cincinnati, OH, 1993

Current Regulatory Requirements, RCRA, Subtitle D, Subtitle C, Hazardous and Solid Waste Amendments

Waste Identification, listed (part 261, Subpart D), (Part 261, Subpart C), characteristic waste; non-specific sources, specific sources, discarded commercial chemical products; characteristics of ignitability, reactivity, corrosivity, or toxicity

Exiting Subtitle C Control; a characteristic waste exists Subtitle C control and may be disposed of in a Subtitle $D$ land disposal facility once the land disposal restrictions have been met; listed waste, or contains a listed waste, or is derived from a listed waste, exiting Subtitle C control is complex; delisting petition; debris contaminated with a listed waste, waste is treated using an extraction or destruction technology

Land Disposal Requirements: The 'Land Ban'; concentration-based standards, specified treatment technologies

Treatability Groups; wastewaters, non-wastewaters, specific items, and debris; Debris, Vitrification is considered by the EPA to be a form of thermal destruction 
Advanced Radioactive Waste-Glass Melters (WSRC-RP-89-1174)

Dennis F. Bickford

American Ceramic Society, Dallas, TX, April 22-26, 1990

Assess the need for continued melter design development to support DWPF and to prioritize future efforts

Glass Furnace Processing of Rocky Flats Plant Wastes - An

Evaluation (MLM-3493)

Larry M. Klingler and Porferio L. Abellera

Monsanto Research Corporation, April 29, 1988

Sludges, filter cake from rotary drum vacuum filters, approximately $66 \mathrm{wt} \%$ water; solar pond sludge

Compositions of Simulated RFP Wastes Used in Glass Melter Processing Study

Ammonia can effectively reduce a high percentage of the $\mathrm{NO}_{\mathbf{x}}$ to nitrogen gas

Dramatic $\mathrm{NO}_{x}$ reduction during periods in which $\mathrm{NH}_{4} \mathrm{OH}$ was being added to the furnace

$\mathrm{NaOH}$ solution used to capture particles and acid gases

$2200 \mathrm{lb}$ of glass was produced

Electric Melting of Nuclear Waste Glasses: State of the Art

C. Chapman, J. M. Pope, S. M. Barnes

J. Non-Crystalline S. 84 (1986) 226-240

\section{Rapid Glass Melting and Refining System}

Ray S. Richards

Proceedings of the 1st International Conference on Advances in the Fusion of Glass, ACS, June 14-17, 1988

Macro Mix Melter, high intensity mixing, electric melter; two foot cube, molybdenum electrodes; $2350-2450^{\circ} \mathrm{C} ; 12$ to 16 ton/day

Glass Furance Project Final Report - An Evaluation of Operating Experience for Low-Level Nuclear Waste Processing (MMM-3229)

Larry M. Klingler and Katherine M. Armstrong

Monsanto Research Corporation, February 28, 1985

Joule-heated glass furnace for treatment of low-level radioactive wastes; cyclone incinerator; offgas system was available; primary function is high-temperature incineration of combustibles

Electrically heated glass melter, wet offgas scrub system; Penberthy Electromelt, Inc.; gas-tight outer skin for radioactivity control and extra external water cooling; resin feed discharge

Fused-cast refractory, alumina, zirconia, and silica; high-purity-iron electrodes; metal addition to the furnace is not permitted

Pressure relief valve, water seal; seal is vented through HEPA filter to a building exhaust duct

Startup by a $400,000-B T U / h r$ propane-fired burner; $150 \mathrm{kVA}, 3$ phase, $460 \mathrm{~V}$ AC; three-phase, phase angle firing SCR unit

Deep Bed Resin; Filter Sludge; Cartridge Filters; Dry Trash; Concentrated Liquids 
Flue gas sample

EPA Method V

After $\sim 21$ months of furnace operation, a furnace electrode failed without warning; intense heat melted the refractory surrounding it; glass drained through the resulting hole and onto the floor where it pooled and hardened

Process and Mechanical Development for the Savannah River TRU Waste Facility

David L. Charlesworth

Spectrum '86, pp. 1787-1796

Large, low-speed shredder and material handling system, a bagless transfer system, a robotically controlled manipulator ("Telerobot"), and an incineration process

TRU waste (mostly $\mathrm{Pu}-238$ and $\mathrm{Pu}-239$ contaminated material) is defined as waste that contains $>100 \mathrm{nCi}$ of alpha-emitting transuranium radionuclides with half-lives greater than 20 years. The noncombustible fraction of the waste consists of decommissioned gloveboxes and process equipment; the combustible fraction includes plastic, cellulose, rubber, and tramp metal and glass from job control waste. About $140,000 \mathrm{ft}^{3}$ of this waste containing $600,000 \mathrm{Ci}$ has been retrievably stored on concrete storage pads within a low-level waste burial ground since 1974 in drums, steel boxes, and drums inside concrete culverts

Sintered metal filters, silica powder precoat system; silica slurried with the ash; HEPA filters shredded and processed

Daugherty, Brent A., Cruber, Lynn M., and Mentrup, Steven J., "Processing of Transuranic Waste at Savannah River Plant," American Nuclear Society International Meeting on Low, Intermediate, and High-Level Waste Management and Decontamination and Decommissioning, September 14-18, 1986 - Niagara Falls, NY.

Stewart, John A., and Charlesworth, David L., "Design and Operation of a Remotely Operated Plutonium Waste Size Reduction and Material Handling Process," Proceedings, Waste Management '86, Tuscon, March 2-6, 1986.

\section{Shredder and Incinerator Technology for Volume Reduction of} Commercial Transuranic Wastes

K. H. Oma

Spectrum '86, pp. 1765-1778

HEPA filters, sample and analytical cell waste, and general process trash; electrically heated controlled-air, gas-heated controlled-air, and rotary kiln; electrically driven, low-speed shredder preferred method for size reduction prior to incineration

Glass Making Technology for High-Level Nuclear Waste

M. D. Boersma, J. L. Mahoney

Proc. Symp. AIChE, Boston, MA, August 1986 
Small High-Speed Glass Melter for Waste Vitrification

R. S. Richards

American Ceramic Society, Dallas, TX, April 1990

Waste Vitrification: A Historical Perspective

J. L. McElroy, W. J. Bjorklund, W. F. Bonner

The Treatment and Handling of Radioactive Wastes, Springer-Verlag (1982) 171-177

Mixed Waste, Proceedings of the Second International Symposium, Baltimore, MD, August 17-20, 1993

A. Alan Moghissi, Richard K. Blauvelt, Gary A. Benda, Nancy E. Rothermich Treatment and Disposal of a Mixed F006 Plating Line Sludge at the Savannah River Site; Reactive Additive Stabilization Process for Hazardous and Mixed Waste Vitrification; Pilot Scale Vitrification Studies on Hazardous and Mixed Wastes; Treatment of Mixed F006 Contaminated Material to Meet the New EPA Debris Rule at the SRS; Critical Operating Parameters for Microwave Solidification of Hydroxide Sludge; The Plasma Hearth Process Technology Demonstration Project

\section{Conceptual Design for Vitrification at West Valley}

J. P. Girauld, J. P. Conard, P. M. Saverot

Proc. 2nd Int. Symp., Ceramics in Nuclear Waste Management 8 (American

Ceramic Society 1983) 134

\section{Plasma Technology for a Better Environment}

M. Orfeuil, D. Bialod, S. L. Camacho (USA), R. C. Eschenback (USA)

Plasma Technology Working Group of the International Union for Electroheat, June 1992

Plasma Furnaces and Reactors

Recovery of Metals from Steelmaking Process Dusts: Scanarc Process, Tetronics/IMS/Multiserv Process, Tetronics British Steel Stainless Process, Mintek Pyromet Process, Davymckee Process, Kawasaki Process

Recycling of Scrap Metal in the Foundry Industry: Plasma Fired Cupola Recovery of Aluminum: Alcan Process

Recovery of Reactive and Refractory Metals from Fines and Scrap: Consolidation Melting-Retech, Hearth Melting-Retech, Leybold Ag Process, Daido Steel Process, Selective Recovery of Metals

Recovery of Platinum Group Metals from Spent Catalyst: Multimetco Tetronics Process, Johnson Matthey Process

Treatment of Hazardous Waste from Chemicals, Destruction of Solid Chemical Waste: Incidis Project, MGC Plasmox Process, Hungarian Electrical Industry Research Institute Process; Nth-Sintef/Kvaerner Engineering, Scanarc Process for Decompositon of Hazardous Waste The Glass Industry: PPG Industries Plasma Melter, Tetronics Manville Melter, British Glass Project 
Radioactive Waste: Plasmarc Process Technology (MGC-Plasma); EDF

(Electricité de France) LTD Process; Volume Reduction of

Noncombustible Radioactive Wastes by Plasma Melting in Japan

Municipal Solid Waste (MSW) and Hospital Waste: Scanarc Process, Krupp

Mak Process for the Treatment of Incinerator Ash and Dust Residues, EDF (Electricité de France) LTD Process, $100 \mathrm{~kW}$ Class Plasma Torch for Ash Melting Plasma Furnaces in Japan, RCL Process, Healthcare Kaiser Unit, Pyrolysis of Hazardous Wastes

Miscellaneous Waste and Processes: New Road for Developments,

Assistance for Combustion, Destruction of Used Tyres and Recovery of

Oil and Carbon; EDG LTD Process for Miscellaneous Wastes

Advanced Radioactive Waste-Glass Melters (WSRC-RP-89-1174)

D. F. Bickford

Westinghouse Savannah River Company, April 1990

\section{Alternate Scrap Melting Technologies Part I}

R. J. Fruehan

I\&SM, March 1987, pp. 15-20

DC Arc Furnaces, Plasma Melting Furnaces; Scrap Preheating and Continuous Melting

Difficulties encountered with DC furnaces are relatively low power for large furnaces, refractory wear and bottom electrode life; main problems with plasma melting furnaces are low amperage torches, refractory wear and bottom electrode and torch life; the units do show promise for the production of alloy steels; in the case of smaller furnaces, DC furnaces currently are competitive with traditional AC electric arc furnaces

\section{Alternate Scrap Melting Technologies Part II}

R. J. Fruehan

I\&SM, April 1987, pp. 9.12

KMS process for increasing scrap melting and KS processs for 100 percent scrap melting

Channel Induction Furnace (Melter-Mixer); a unit with two $6 \mathrm{MW}$ inductors for a $12 \mathrm{MW}$ total can melt 24 metric tons of scrap per hour; overall electrical efficiency is about 91 percent

Plasma-Assisted Cupola; nontransferred arc plasma generator is located in the tuyere zone of a refractory-lined cupola: 2.5-ton-per-hour pilot scale cupola, $2 \mathrm{MW}$ plasma torch

\section{Enviroglass $^{\mathrm{TM}}$ Vitrification Technology for Low Level Radioactive Waste}

J. Bradley Mason

Pacific Nuclear, Plant Services Group,1993

Pacific Nuclear and Battelle Memorial Institute; wastes include Dry Active

Wastes (DAW), ion exchange resins, chemical cleaning and decontamination solutions, inorganic sludges and slurries, medical 
wastes and mixed wastes; design criteria functions: waste feed, gasifier/melter, off-gas control, and auxiliary systems

Mobile; fixed base and mobile systems

EPA Proposed Treatment Standards (mg/L)

\begin{tabular}{||l|c|c|}
\hline \multicolumn{2}{|c|}{ Table 2. EPA Proposed Treatment Standards (mg/L) } \\
\hline Heavy Metals & $\begin{array}{c}\text { Existing } \\
\text { Limits (TCLP) }\end{array}$ & $\begin{array}{c}\text { Proposed } \\
\text { Non-Wastewater } \\
\text { Limits (TCLP) }\end{array}$ \\
\hline Antimony (1) & NA & 2.1 \\
\hline Arsenic & 5.0 & 5.0 \\
\hline Barium & 100.0 & 7.6 \\
\hline Berylium & NA & 0.014 \\
\hline Cadmium & 1.0 & 0.19 \\
\hline Chromium (1) & 5.0 & 0.33 (total) \\
\hline Lead & 5.0 & 0.37 \\
\hline Mercury & 0.2 & 0.009 \\
\hline Nickel (1) & NA & 5.0 \\
\hline Selenium & 1.0 & 0.16 \\
\hline Silver & 5.0 & 0.30 \\
\hline Thallium & NA & 0.078 \\
\hline Vanadium (1) & NA & 0.23 \\
\hline Zinc (1) & NA & 5.3 \\
\hline \hline NOTES: (1) Principal metals that impact chemical decon and cleaning wastes \\
\hline
\end{tabular}

Stabilization of Wastes for Burial; Tests Requirements; Design and Construction of Radwaste Processing Facilities; Transportation

Codes and Standards; Mechanical Systems, ASME Boiler and Pressure Vessel Code, Electrical Systems

Nonhazardous; therefore, a RCRA " $\mathrm{B}$ " permit is not required unless mixed wastes are to be processed

Module Enclosure; Shielding; Throughput; Volume Reduction; Glass Durability; Atom-for-Atom Accountability; Volatile Metals; Off-Gas; Safety

Waste Feed System; Gasifier/Melter System; Glass Handling; Off-Gas Control; Auxiliary Systems 


\section{State-of-the-Art of Waste Glass Melters}

Chris Chapman

Ceramic Transactions-Advances in Fusion and Processing of Glass,

Vol. 29, 1993, pp. 485-493

Land disposal; Volume Reduction

Melter Technologies; High-Level Radioactive Waste Melters; History and Design Evolution of High-Level Waste Glass Melters; Commercial Glass Melters, Terra-Vit; Short Residence Time, Intensive Melters; Electric Arc Furnace; Co-current Fossil Fuel Firing and Waste Melting; Mechanical Stirring; Slagging Pyrolysis

\section{Electric Melting of Glass}

Roy A. Mudway

Proceedings of the Ist International Conference on Advances in the Fusion of Glass, ACS, June 14-17, 1988

Pot furnaces, molybdenum disilicide elements, direct and indirect electric heat

Molybdenum electrodes, Kanthal Super elements; Bubbler Tubes

\section{Waste Vitrification - Choice of Melter}

Douglas $H$. Davis, Irving $M$. Williams

All-electric cold-top melter; no single best answer; differences in raw materials, energy pricing, glass tonnage requirements that dictate different choices

Prepare waste materials; mix waste and other raw materials; adjust glass composition; control glass composition; hold emissions; final product

Incineration Plus Vitrification in one unit, physically feasible, often not the best answer

Metallic spheres or pools at the bottom of the melter if excessively reducing Hot-Top Melters; Lacks Condensing Feature of the Cold Top; Cold Top Melters - Non-Convective Versus Convective; Non-Convective Cold Top Electric Melters; High-Intensity, Convective Cold Top Melters

\section{Cold Crown Vitrification of Muncipal Waste Combustor Flyash (93- RA-117.02)}

Dale R. Wexell

Air \& Waste Management Association Annual Meeting, Denver, CO, June 1318,1993

Lead, cadmium, chromium, and zinc are high vapor pressure metals EPA sponsored vitrification as a treatment process for MWC residues

Two serial aqueous extractions of the APC residue, drying at $500^{\circ} \mathrm{C}$, vitrification technology requires glass batch not in excess of 5\% chloride; blending of the dechlorinated APC residue with glass forming additives; melting into a homogeneous glass in a cold crown melter; $1200-1550^{\circ} \mathrm{C}$, waste volume was reduced

Melter ash product at rates of $4-18 \mathrm{~kg} / \mathrm{hr}, 19 \mathrm{~kg}$ of glass at capacity Bench Scale Melter

Intermediate Scale Electric Melter, charged at $1450^{\circ} \mathrm{C}$ with $193.2 \mathrm{~kg} ; 9-11$ $\mathrm{kg} / \mathrm{hr}$; a cold crown in excess of $1 \mathrm{~cm}$ thickness 
TCLP; Availability Leach Test (ALT); Accelerated Strong Acid Durability (ASAD) test

Lead could be retained in the APC residue during dechlorination by maintaining pH $9.8 ; 30 \%$ of the calcium, $60 \%$ of the potassium, $17 \%$ of the sodium, $20 \%$ of the lead, and $19 \%$ of the sulfur represent in the untreated APC residue also were removed in the dechlorination process

Studied $\mathrm{Na}_{2} \mathrm{O}-\mathrm{CaO}-\mathrm{Al}_{2} \mathrm{O}_{3}-\mathrm{SiO}_{2}$ system; 40-56\% APC residues

Initial Demonstration of the Vitrification of High-Level Nuclear Waste Sludge Containing an Organic Cs-Loaded Ion Exchange Resin (WSRC-MS-91-465)

N. E. Bibler, J. P. Bibler, M. K. Andrews, C. M. Jantzen

Westinghouse Savannah River Company, 1991

Resorcinol based organic ion exchange resin; successfully vitrified in a jouleheated, slurry fed melter; reduction of Fe(III) in the melt

Cs-137, $1150^{\circ} \mathrm{C}$; Crucible Tests; Effect of Resin on Melter Operation; Effect of Resin on Glass Redox and Durability

Penberthy Electromelt International, Inc.

Meeting, Seattle, WA, September 21, 1993

Electrodes and materials: chrome iron alloy; high purity iron; graphite, horizontal; graphite, vertical; molybdenum rods, horizontal, vertical from bottom and from top

Operating mode: cold top; hot top

Alumino-silicate

PEI's Demo Glass Furnace Facilities: 1 ton/day batch blanket; 4 tons/day for RCRA; 6 tons/day for HLW; mockup of 2.4 tons/day, mineral-type batch

Cornelius/Penberthy furnace, alumino-silicate: 28-32 tons/day; 85 such furnaces, 35 are in the span of 30-135 tons of glass per day

Penberthy Electromelt International, Inc.

Seattle, WA, February 24, 1981

The Structure of Glass as a Host for Radwaste

United States Patent 4,299,611

Penberthy, November 10, 1981

Elongate enclosed conversion chamber, Joule effect; ceramic fiber filter

Penberthy Electromelt International, Inc.

September 21, 1993

6 ton/day melter built and operated for the West Valley Demonstration

Project, 2 × 2 foot square $(800 \mathrm{~kg} /$ day) molybdenum electrode melter;

"Pyro Converter", 1989-1991; RCRA hazardous waste incineration and immobilization

Alumina-silica, calcia-alumina-silica; soda lime silica glasses

Alumina-silica, Atomic Energy Canada, LTD, buried in the 1950 s

Commercial electric glass furnaces, capacity in excess of 100 tons per day 
Clear flint glass production molybdenum electrodes consumed at a rate of about two inches per month

Decontamination factors for potentially volatile waste components such as $\mathrm{Cs}, \mathrm{Tc}, \mathrm{Ru}$ and Se need to be demonstrated for a high temperature $\left(1250^{\circ} \mathrm{C}\right.$ or greater) batch blanket melter

High Temperature Melter (HTM), slurry fed joule-heated melter using top fed vertical molybdenum electrodes

Remote electrode advancement through the melter side wall need to be evaluated

Thermal Processing System Concepts and Considerations for RWMC Buried Waste (EGG-WTD-10058)

T. L. Eddy, P. C. Kong, B. D. Ralvo, G. L. Anderson

Idaho National Engineering Laboratory

Five practicable thermal process system design concepts are defined and compared

Processing with no complex presorting using incineration and high temperature melting is recommended

CERCLA; heterogeneous mixture; combustibles and noncombustibles; RCRA

Thermal processing system enclosed for alpha containment; thermal desorption, then incinerator; gaseous products of incomplete combustion to an afterburner; offgas treatment system removes volatilized metals and metal oxides, halogen and sulfur compounds (acid gases)

Noncombustible solids fed melter in a semicontinuous mode; cold cap over slag melt; 3-phase, AC graphite electrode submerged-arc melter; other types possible (DC arc, plasma torch); liquid metal tapped; barrels of slag are tapped, cooled under a controlled schedule to form the desired glass/ceramic

High vapor pressure (volatile) metals (HVPMs) such as $\mathrm{Pb}, \mathrm{Zn}, \mathrm{Hg}, \mathrm{Cs}-137$ expected to be oxidized and returned to some extent to the slag; metal vapors collected downstream; vitrify at lower temperature

Approximate mass flow diagram

Considered phosphate, borosilicate, high alumina-silicate glasses, ironenriched basalt, Synroc, and other glass-ceramics

Sorting Options: A) no separations and no incinerator; B) separation of combustibles; C) separation of noncombustibles, combustibles, and metals; D) separation of bulk metals only; and E) no separation with an incinerator for the entire input waste stream

Scenario I, Incineration and Melting with Postsort TRUW \& LLW

Scenarios II, III, and IV, variations on Scenario I in different configurations; Scenario V assumes BSG

Melter Processes-Fluidity, Electrical Conductivity, Corrosion, Slag Chemistry and Retention of TRU Nuclides, Control of HVPM, Vitrification/Devitrification Processes

Potential problems and possible fixes for the various material categories

Recommended as-separated classification of input waste streams 
Criteria and Requirements for Final Waste Form - Borosilicate Glass (BSG); High Alumina-Silicate Glasses; Iron-Enriched Basalt (IEB); Glass-

Ceramics; Phosphate Glasse. Synroc

Radiological Assays

Processes in the Melter - Physical Processes in the Melter; Chemical

Processes in the Melter: Combustion and Pyrolysis, Disposition and

Influence of Halides, Oxidation of Metals, Slag-Chemistry Processes,

Retention of HVPMs, Retention of TRU, Retention of LL

Radionuclides, Redox State of the Melt, Electrode Corrosion and

Erosion

Recommended R\&D and Priorities; Proposed Testing

An Advanced Technology for the Vitrification of Contaminated Soils

J. G. Hnat, A. Mathur, M. J. Zientek, P. T. Myles

American Ceramic Society Annual Meeting, Cincinnati, OH, 1993

Pilot-scale Combustion and Melting System (CMS); description of Vortec's

CMS, results from the vitrification testing performed on a surrogate soil

Process Description; Combustion and Melting System; Process Applications; Schematic of the Process; Pilot Plant Operating Parameters; TCLP

\section{A Plasma Centrifugal Furnace for Treating Hazardous Waste, Muttenz, Switzerland \\ Electrotech 92, Montreal, June 15-18, 1992}

M. R. Funfschilling, MGC Plasma Ltd.; R. C. Eschenback, Retech, Inc.

One ton/hour (usually 4 or 5 drums); two plasma torches; burning in reaction chamber and secondary combustion chamber; oxygen lance in reaction chamber; secondary combustion at $1200^{\circ} \mathrm{C}$

Drumed Handling, pierced drums

$\mathrm{deNO}_{\mathbf{x}}$ section; ammonia is added, catalyst bed to remove $\mathrm{NO}_{\mathbf{x}}$; water treatment system

Plasma Arc Vitrification

Richard C. Eschenbach

EPA Fourth Forum on Innovative Hazardous Wastes Treatment Technologies, San Francisco, CA, November 1992

Centrifugal Furnace process

Current Status of the Plasma Centrifugal Furnace in Treating Hazardous Wastes (For presentation of the Plasma Materials Science Committee of the Japan Society for the Promotion of Science)

Dr. Richard C. Eschenbach

Retech, Inc.

Swirl-stabilized plasma torch

Destruction and removal efficiency (DRE); hexachlorobenzene, $99.9968 \%$ to 99.9999\%; total hydrocarbons in the exhaust $<4 \mathrm{ppm}$; $\mathrm{CO}$ in the exhaust averaged $1.4 \mathrm{ppm}$

Swiss, MGC Plasma, 1990

Whole drums inserted, five at a time; some problems 
Supersonic oxygen jet; molten steel covered with slag could be oxidized to make a single homogeneous slag

Fly ash from municipal solid waste incincerator; analytical results not available

Pyrotechnics, thermal batteries, contaminated soil, ash from past outdoor burning could be satisfactorily treated

System Diagram

Oxidizing a Metal Sub-Layer

Cross Section

\section{PLASMARC@ PLASMAREC@ Mobile Station}

Moser-Glaser (MGC) Energy and Plasma Technology

Schematics of reactor vessel

Trucking arrangement

Cooling circuits and gas control

Container systems for transportation on site

Mobile plasma unit is mounted on 2 flat rack container systems

Control + hydraulics

Technology Demonstration Summary (EPA/540/S5-91/007, Aug. 1992)

Technology Evaluation Report; SITE Program Demonstration Test

Retech, Inc. Plasma Centrifugal Furnace; Butte, MT, July 1991

Soil $10 \%$, No. 2 diesel oil; at least a $99.99 \%$ Destruction and Removal

Efficiency (DRE); particulate emissions exceeded the RCRA regulatory limit; combustion of organic compounds was complete, inefficient capture of particulates; cost per ton, dependent on the feed rate

TCLP Results for Demonstration Tests - Metals: Aluminum, Barium, Cadmium, Calcium, Copper, Iron, Magnesium, Manganese, Nickel, Potassium, Sodium, Vanadium, Zinc.

Semivolatiles: Hexachlorobenzene, 2-Methylnapthalene, Napthalene

DRE Results - Hexachlorobenzene, 2-Methylnapthalene

Stack Gas Composition

Economic Analysis: Estimated Costs in \$/Ton; Estimated Costs in \$/Ton for

Various Feed Rates and On-line Operating Conditions

Community Acceptance

Microwave System Optimization (OR132005)

T. L. White, G. D. Del Cul

Mixed Waste Integrated Program Meeting, February 25-26, 1993

Advantages of Microwave Heating; ORNL Microwave Solidification Program;

Rocky Flats Microwave Solidification

\section{Critical Operating Parameters for Microwave Solidification of}

Hydroxide Sludge

G. S. Sprenger, V. G. Eschen

Proceedings of the Second International Symposium on Mixed Waste,

Baltimore, MD, August 17-20, 1993, pp. 7.1.1-7.1.5

Microwave energy to heat and melt the waste into a vitreous final form that is suitable for land disposal; in-container treatment; Toxicity 
Characteristic Leach Procedure; results from tests on a surrogate hydroxide spike with heavy metals

Site Test Results with the PCF-6

Rob Haun, Richard Eschenbach, Dan Battleson, Trevor Jackson

Plasma Centrifugal Furnace

Feed rate, 100-120, lb/hr; Electrode life, $~ 50, \mathrm{~h} \mathrm{r}$

Oxygen lance; Afterburner

Primary chamber temperature, $>2,100,{ }^{\circ} \mathrm{F}$

DRE Results for Demonstration Tests - Hexachlorobenzene, $>99.9968 \%$ to $>99.9999 \%$

Slag Leach Resistance; TCLP

\section{TCLP Results on Microwave Solidified Surrogate Hydroxide}

Coprecipitation Sludge

G. S. Sprenger, V. G. Eschen (EG\&G Rocky Flats), R. D Petersen

April 9, 1993

Microwave Solidification, Immobilization, Sludge, Hydroxide Sludge, TCLP

Results from tests performed on surrogate hydroxide coprecipitation sludge spiked with heavy metals at elevated concentrations

Japanese converting plutonium nitrate to plutonium oxide: Laboratory scale vitrification of high-level wastes, INEL, 1979; RFP since 1986; demonstration scale system; FBI ashes, nitrate salts, soils

FBI ashes included chromium oxide catalyst and shredded HEPA filters; Nitrate salts to melting points forming a salt cake

Viscosity of melt can be higher than glasses; crystalline materials, heat is contained in drum

Table I. Metal Concentrations in ppm

Surrogate Sludge Actual Sludge

$\begin{array}{lll}\text { Chromium } & 500 & 54 \text { to } \mathbf{4 8 1} \\ \text { Nickel } & 500 & \text { no data } \\ \text { Lead } & 500 & 29 \text { to } 250 \\ \text { Cadmium } & 500 & 4.6 \text { to } 13.0 \\ \text { Silver } & 500 & 56 \text { to } 189\end{array}$

Borax, diatomaceous earth, in the frit feed; waste loading; temperature, quench rate

TCLP Results; Impact of Operating Parameter

Waste loading was most critical operating parameter impacting leachability; leach results increased as the waste loading increased; slight response observed for frit composition; increasing borax can lead to undesirable leachability

Temperature and quench rate did not impact significantly TCLP leachability EPA Constituent Concentrations in Waste Extract (CCWE); for F006 wastes, chromium, nickel were within the limits; lead and silver exceeded the limit; higher waste loading levels; cadmium exceeded the limit, nearly all cases 
Table V. EPA Constituent Concentrations in Waste Extract

Metal Constituent

Cadmium

Chromium

Lead

Silver

Nickel
EPA Code

D006

F006

D007

F006

D008

F006

D011

F006

F006
CCWE Limit (ppm)

1.0

0.066

5.0

5.2

5.0

0.51

5.0

0.072

0.32

Bench-Scale Arc Melter for R\&D in Thermal Treatment of Mired Wastes (EGG-MS-10646)

P. C. Kong, J. D. Grandy, A. D. Watkins, T. L. Eddy, G. L. Anderson

Idaho National Engineering Laboratory

Applications, System Design and Construction, Data Acquisition, Melting

Capability, Electrode Wear, Energy Balance

Mechanical Schematics, Electrical Schematics

Modified IRC Bench-Scale Arc Melter for Waste Processing (Draft) (EGG-MS-10941)

T. L. Eddy, J. W. Sears, J. D. Grandy, P. C. Kong

Idaho National Engineering Laboratory

Melter Modifications

Melt chamber, electrode assembly, auger feeder, offgas sampling, slag sampling, data logger, air flow, temperature measurement, video monitor, air lance

Volatilization without a Cold Cap, Volatilization with a Cold Cap, Effect of Redox Conditions, Electrode Erosion, Energy Balance

Summary of INEL Research on the Iron-Enriched Basalt Waste Form (EGG-WTD-10056)

G. A. Reimann, J. D. Grandy, T. L. Eddy, G. L. Anderson

Idaho National Engineering Laboratory

Applicability of IEB in converting retrieved transuranic (TRU) waste to stable waste form; borosilicate glass appears unsuited for this application; IEB requires processing temperatures of 1400 to $1600^{\circ} \mathrm{C}$; using Joule-heated melters has proved difficult because of electrode and refractory corrosion; melters (arc and plasma) are available to produce this final waste form; IEB will accommodate and stabilize a wide range of heterogeneous waste materials, including long-lived radionuclides and scrap metals; controlled cooling and heat treatment produce a glass-ceramic waste form with superior leach resistance; future work includes retention and dissolution of TRU oxides in the IEB with zirconia; high vapor pressure metals, including $\mathrm{Cs}, \mathrm{Pb}$, and $\mathrm{Hg}$; controlled cooling for minimum leaching; processing with plasmatorch and/or arc-heated melters 
$\mathrm{ZrO}_{2}$ enables development of host crystals which incorporate uranium oxide and form highly leach resistant materials; controlled cooling, a fine crystalline structure, which produced much smaller leach rates than $\mathrm{BSG}$; without $\mathrm{ZrO}_{2}$, uranium precipitates as a separate oxide; plutonium behaves similar; affinity of zirconia for uranium demonstrated, affinity for $\mathrm{Pu}$ and other TRUs was not determined Temperatures high $\left(1400-1600^{\circ} \mathrm{C}\right)$; much of the cesium remained in the slag Viscosity and electrical conductivity were measured; solubility limits of oxides in IEB were determined; aluminum scrap generate excessive alumina causing the melt to freeze; fluorides improved viscosity but accelerated refractory corrosion; lower temperature improved refractory life, cause undesirable crystallization, develops layer on the furnace bottom

Mo electrodes; ruby refractory brick best but corroded near the slag-air interface; electrode oxidation significant

Uranium did not migrate into or otherwise accumulate in the refractories; bubblers hasten oxidation; iron gradually oxidizes ; bubbler increased oxidation rate

Table 2. Compositions (Major Oxide Components) of Selected Wastes, Soil (without Volatiles), Nominal IEB, ${ }^{5,9}$ and Natural Basalt. ${ }^{7}$

\begin{tabular}{|c|c|c|c|c|c|c|c|c|c|}
\hline & & & Dxide Co & sunds & vt\%) & & & & \\
\hline & $\mathrm{SiO}_{2}$ & $\mathrm{Al}_{2} \mathrm{O}_{3}$ & $\begin{array}{l}\mathrm{FeO}+ \\
\mathrm{Fe}_{2} \mathrm{O}_{3} \\
\end{array}$ & $\mathrm{CaO}$ & $\mathrm{MgO}$ & $\mathrm{Na}_{2} \mathrm{O}$ & $\mathrm{K}_{2} \mathrm{O}$ & $\mathrm{B}_{2} \mathrm{O}_{3}$ & Other \\
\hline A-O & 38.0 & 7.4 & 34.5 & 8.3 & 4.6 & 4.8 & 2.4 & - & $\cdots$ \\
\hline B-O & 42.6 & 4.3 & 19.1 & 14.1 & 7.8 & 9.4 & 2.6 & - & - \\
\hline $\mathrm{C}-\mathrm{O}$ & 2.8 & 1.8 & 91.3 & 3.5 & 0.5 & 0.03 & 0.1 & $\cdots$ & -- \\
\hline $\begin{array}{l}\text { RWMC Soil } \\
(A-100)\end{array}$ & 65.4 & 12.5 & 4.8 & 9.6 & 2.5 & 1.5 & 29 & - & $\begin{array}{l}0.7 \\
\left(\mathrm{TiO}_{2}\right)\end{array}$ \\
\hline $\mathrm{BSG}^{\mathrm{a}}$ & 50.7 & 4.3 & 15.2 & 1.0 & 0.7 & 9.8 & $\begin{array}{c}5.2 \\
\left(\mathrm{Li}_{2} \mathrm{O}\right)\end{array}$ & 7.1 & 6.5 \\
\hline IEB $(A-40)$ & 51.0 & 10.3 & 19.6 & 9.7 & 3.5 & 3.2 & 2.6 & $\cdots$ & - \\
\hline Natural Basalt & $45-55$ & $13-17$ & $11-14$ & $7-10$ & $4-10$ & $2-4$ & 1.5 & -- & $\begin{array}{l}1-1.5 \\
\left(\mathrm{TiO}_{2}\right)\end{array}$ \\
\hline
\end{tabular}

a. SRL 165 frit $+30 \%$ simulated waste. 


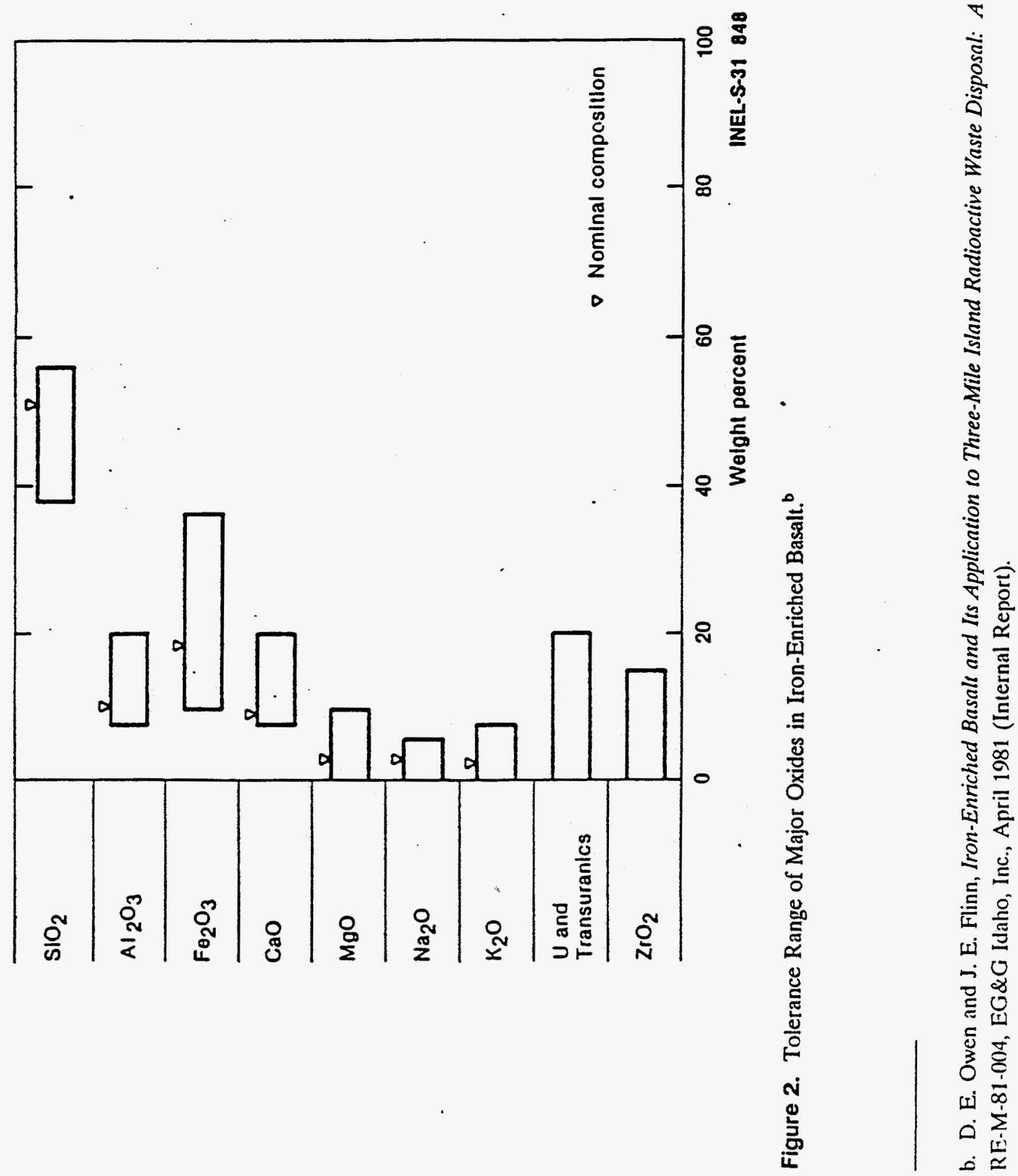


Table 3. Refractories tested in the slag-refractory interaction tests

Remmy A-1a - Pressed and sintered $\mathrm{SiC}$ grains (85\%) with ceramic binder

Remmy Za . Pressed and isnered $\mathrm{ZrO}_{2}$

99-ADa (Sintered ) $99 \% \mathrm{Al}_{2} \mathrm{O}_{3}$

B-98a . Sintered (burned) $98 \% \mathrm{MgO}$

Delta $1^{\mathrm{a}}$ Pressed and sintered $60 \% \mathrm{MgO}-40 \% \mathrm{Cr}_{2} \mathrm{O}_{3}$ Rubyb Pressed and sintered $90 \% \mathrm{Al}_{2} \mathrm{O}_{3}-10 \% \mathrm{Cr}_{2} \mathrm{O}_{3}$

a. Trade name, A. P. Green Refractories Co., Mexico, Missouri

b. Trade name, Harbison-Walker Refractory Co.

Pyroxene [augite, or augitic pyroxene, $\mathrm{Ca}(\mathrm{Mg}, \mathrm{Fe}, \mathrm{Al})(\mathrm{Si}, \mathrm{Al})_{2} \mathrm{O}_{6}$ ] crystals on magnetite nuclei

Plagioclase and other feldspar crystals

$\mathrm{ZrO}_{2}$ (baddeleyite); $\mathrm{ZrO}_{2}$ should be added, about $20 \%$ of the uranium content Zirconolite ( $\mathrm{Ca} \mathrm{Zr} \mathrm{Ti}_{2} \mathrm{O}_{7}$ ) could be precipitated

$\mathrm{TiO}_{2}$ of 0.6 to 1.0 wt\%

Residual glass becomes richer in Cs as IEB devitrifies

Viscosity; heat capacity; fracture toughness, splitting tensile strength, vibration, microindentations with microhardness, and laboratory-scale impact

MCC-1 Static Leach Test; Soxhlet test; leach rates unacceptably high when alkali metal oxides exceed $10 \% ;{ }^{237} \mathrm{~Np}$ had the highest leach rates; 182 days 
Table 5. Comparison of uranium leach rates for a number of nuclear waste forms. ${ }^{13}$

\begin{tabular}{|c|c|c|c|c|}
\hline & \multicolumn{3}{|c|}{ Uranium Leach Rate $\left(\mathrm{g} / \mathrm{m}^{2} \cdot \mathrm{d}\right)$} & \multirow{2}{*}{$\begin{array}{c}\text { Waste form } \\
\text { U content } \\
\text { (wt\%) }\end{array}$} \\
\hline & Deionized water & Brine & Silicate Water & \\
\hline Fine-grained IEB & $0.009 \pm 0.002$ & $0.0027 \pm 0.0004$ & $0.013 \pm 0.001$ & 13.3 \\
\hline Coarse-grained IEB & $0.0059 \pm 0.0003$ & $0.0064 \pm 0.0019$ & $0.016 \pm 0.003$ & 13.3 \\
\hline Borosilicate glass $^{\mathrm{a}}$ & $0.055 \pm 0.003$ & $<0.019$ & $0.236 \pm 0.002$ & 1.0 \\
\hline High-silica glass $^{\mathbf{a}}$ & $0.052 \pm 0.005$ & $<0.020$ & $0.081 \pm 0.007$ & 1.1 \\
\hline Tailored Ceramic ${ }^{\mathbf{a}}$ & $0.005 \pm 0.005$ & $<0.014$ & $0.014 \pm 0.006$ & 2.1 \\
\hline SYNROC & $<0.002$ & $<0.014$ & $0.001 \pm 0.001$ & 2.1 \\
\hline
\end{tabular}

a. Reference 22 . 
Ion exchange resins; phenolic, sulfonated, and quaternary amine types; decomposed slowly; phenolic oily soot, which could be ignited; resins decomposed quickly when pressed beneath the melt surface; when blown into the furnace, resins ignited readily but were swept out the exhaust stack; on the bath surface, the resins could be destroyed at a rate of $1350 \mathrm{~g} / \mathrm{h}, 2.6 \mathrm{~g} / \mathrm{h} / \mathrm{cm}^{2}$

Refractory lining remains as the limiting factor determining furnace life $\mathrm{Al}_{2} \mathrm{O}_{3}$ and $\mathrm{Al}_{2} \mathrm{O}_{3} \cdot \mathrm{Cr}_{2} \mathrm{O}_{3}$ seemed to resist chemical diffusion of TRU Bibliography

- Stone 79 (DP-1545) reports on preliminary evaluations of alternate forms for immobilization of Savannah River Plant high-level waste.

- Flinn-80 (MRS Sci. Basis for Nuclear Waste Management, 1980) summarizes the evaluation of four $90 \mathrm{~kg}$ slag castings electromelted (at Penberthy) approximating INEL soil and wastes. Phase and microstructure, leaching and mechanical behavior are discussed.

- Flinn-81 (Scientific Basis for Nuclear Waste Management, 3, 1981) characterizes iron-enriched synthetic basalt for TRU containment.

- Sill-81 (LR-81-09-04) investigates volatility of cesium and strontium from a synthetic basalt.

- Welch-81 (EGG-J-3181) discusses IEB as a TRU waste form. Samples were tested for leaching resistance and fracture toughness. The volatility of $\mathrm{Cs}$ and $\mathrm{Sr}$ from an IEB melt is assessed.

- Welch-81 (EGG-M-5181) reports on IEB containment of transuranic waste sludges.

- Kelsey-82 (Scientific Basis for Nuclear Waste Management, 4, 1982) applies the IEB waste form to TMI radioactive waste disposal. Zeolite, core debris, stainless steel, and $\mathrm{UO}_{2}$-Zircaloy dissolution tests are described.

- Owen-82 (Treatment and Handing of Radioactive Wastes Conf., 1982) presents the application of IEB to TMI radioactive waste disposal.

- Welch-82 (EGG-FM-5709) immobilized RFP/TRU with glass-ceramics. A 741-2 sludge with and without Am-241 was produced in a melter, followed by controlled cooling. Compositions and cooling were varied. Testing included an assessment of microstructures and leach tests, which depended on temperature and indicated differing Am-241 leach rates.

- Welch-83 (EGG-FM-6059) reports conditions for TMI core debris to be assimilated by IEB. Tests included loading limits, dissolution rate increases due to bubbling, fracture toughness, and splitting tensile strength. Recovery of uranium is also discussed.

- Welch-83 (EGG-FM-6153) reports leach tests on slag containing low level $(1 \mu \mathrm{Ci} / \mathrm{g})$ TRU (Np-237, Pu-239, Am-241, Cm-244) from a simulated slagging pyrolysis incinerator. Tests were made on the original frit, concrete monoliths made with portland cement, and vitrified monoliths of INEL soil and simulated INEL waste and RFP/TRU sludge. 
Improving Iron-Enriched Basalt with Additions of $\mathrm{ZrO}_{2}$ and $\mathrm{TiO}_{2}$ (EGG-MS-10642, Rev. 1)

G. A. Reimann, P. C. Kong

Idaho National Engineering Laboratory

Iron-enriched basalt modified by adding sufficient $\mathrm{ZrO}_{2}$ and $\mathrm{TiO}_{2}$ to develop zirconolite upon cooling, $5 \%$ each of $\mathrm{ZrO}_{2}$ and $\mathrm{TiO}_{2}$ slow-cooled in the $1200-1000^{\circ} \mathrm{C}$ range, actinide surrogates incorporated into the crystals of zirconolite, precipitates zirconolite from a cooling basaltic melt

$0.5 \%$ each of $\mathrm{CeO}_{2}, \mathrm{Eu}_{2} \mathrm{O}_{3}, \mathrm{Gd}_{2} \mathrm{O}_{3}, \mathrm{Nd}_{2} \mathrm{O}_{3}$, and $\mathrm{Sm}_{2} \mathrm{O}_{3}$. Lanthanides were concentrated from $0.5 \%$ each to nearly $8 \%$ in the zirconolite

Additions of $\mathrm{ZrO}_{2}$ and $\mathrm{TiO}_{2}$ to generate stable host crystals for transuranic (TRU) elements

Leach resistance of "devitrified" IEB was found to be superior to vitreous IEB and equal to or better than other vitreous waste forms, crystalline phases during cooling depletes the residual glass phase elements that affect leaching; alkali and alkaline-earth metals, $\mathrm{Na}_{2} \mathrm{O}, \mathrm{CaO}$, and $\mathrm{MgO}$. Contents decreased from 18 to $5 \% ; \mathrm{SiO}_{2}+\mathrm{Al}_{2} \mathrm{O}_{3}$ content increased from 59 to $90 \%$.

Ziron $\left(\mathrm{ZrSiO}_{4}\right) 1.8 \times 10^{8}$ to $1.7 \times 10^{9}$ years

Zirconolite ( $\mathrm{CaZrTi}_{2} \mathrm{O}_{7}$ ), samples containing up to $20.5 \% \mathrm{ThO}_{2}+1.7 \% \mathrm{U}_{3} \mathrm{O}_{8}$ $>2 \times 10^{9}$ years

Calzirite $\left(\mathrm{CaTiZr}_{3} \mathrm{O}_{9}\right)$ incorporates actinides and lanthanides in lesser amounts than zirconolite

Sphene (CaSiTiO5)

Perovskite $\left(\mathrm{CaTiO}_{3}\right), \mathrm{Ca}$-free varieties up to $27 \%$ rare earth elements and $13 \% \mathrm{ThO}_{2},>5 \times 10^{8}$ years

Ringwood: Zirconolite becomes completely metamict at dosages $>2 \times 10^{19}$ alphas per gram, $>1 \times 10^{20}$ alphas per gram no appreciable quantity of Th or $U$ was lost, $36 \%$ retention of the helium.

Synroc, zirconolite, perovskite, and Ba-hollandite $\left(\mathrm{BaAl}_{2} \mathrm{Ti}_{6} \mathrm{O}_{16}\right)$, zirconolite can accommodate up to $27 \mathrm{wt} \% \mathrm{UO}_{2}, 22 \mathrm{wt} \% \mathrm{ThO}_{2}, 29 \mathrm{wt} \%$ intermediate $\mathrm{REE}$ oxides, $25 \mathrm{wt} \% \mathrm{Nb}_{2} \mathrm{O} 5,7 \mathrm{wt} \% \mathrm{Al}_{2} \mathrm{O}_{3}, 4 \mathrm{wt} \% \mathrm{MgO}, 9$ wt\% $\mathrm{Fe}_{2} \mathrm{O}_{3}$, and at least 5 wt\% $\mathrm{MnO}$

Rare earth elements as surrogates for actinide elements, preliminary data for Time-Temperature-Crystallization (TTC) curves

$\mathrm{CeO}_{2}, \mathrm{Eu}_{2} \mathrm{O}_{3}, \mathrm{Gd}_{2} \mathrm{O}_{3}, \mathrm{Nd}_{2} \mathrm{O}_{3}$, and $\mathrm{Sm}_{2} \mathrm{O}_{3}, 0.5 \mathrm{wt} \%$ (2.5 wt\%, total), five percent each $\mathrm{ZrO} 2$ and $\mathrm{TiO} 2$

Induction melting, Arc melting, carbon electrodes, combination of both the heat of the arc and Joule heating, 8 and $10 \mathrm{~kg}, 4 \mathrm{~g}$ at $1500^{\circ} \mathrm{C}$ for 1 hour in air, 1200,1100 , and $1000^{\circ} \mathrm{C}$ up to 24 hours for crystallization, induction crucibles have poor geometry for foamy melts

Crucible zircon $\left(\mathrm{ZrSiO}_{4}\right)$, spinel is $\mathrm{Mg}_{3} \mathrm{Al}_{2} \mathrm{O}_{4}$, plagioclase $\left(\mathrm{CaAl}_{2} \mathrm{Si}_{2} \mathrm{O}_{8}\right)$, albite $\left(\mathrm{NaAlSi}_{3} \mathrm{O}_{8}\right)$, augitic pyroxene or augite $\mathrm{Ca}\left(\mathrm{Mg}, \mathrm{Fe}{ }^{+2}, \mathrm{Al}\right)(\mathrm{Si}, \mathrm{Al})_{2} \mathrm{O}_{6}$ Hematite, Magnetite, Pseudobrookite

Zirconolite ( $\mathrm{ZrCaTi}_{2} \mathrm{O}_{7}$ ) capture and retain $\mathrm{REE}$ actinide surrogates, $5 \mathrm{wt} \%$ each of $\mathrm{ZrO}_{2}$ and $\mathrm{TiO}_{2}$ will develop zirconolite, $2: 1 \mathrm{TiO}_{2}: \mathrm{ZrO}_{2}$ may be preferable 
Investigations of the Properties of Iron-Enriched Basalt with $\mathrm{TiO}_{2}$ and $\mathrm{ZrO}_{2}$ Additions

J. G. Conley $(U W V)$, P. V. Delsey and D. V. Miley (EG\&G Idaho, Inc.) Nuclear Waste Management, Advances in Ceramics, Vol. 8 (1984), The American Ceramic Society, Columbus, OH pp. 302-309

$\mathrm{ZrO}_{2}$ and various $\mathrm{TiO}_{2}$ additions, phase equilibria, microstructural development, zirconolite $\left(\mathrm{CaZrTi}_{2} \mathrm{O}_{7}\right)$, optimum composition and cooling cycle determined, MCC-1 procedures. Zirconolite that formed effectively scavenged all of the actinides examined except neptunium.

Uranium, gadolinium, and cerium oxides, DTA, optimum $\mathrm{TiO}_{2}$ loading and cooling cycle, $1500^{\circ} \mathrm{C}$ for $0.5 \mathrm{~h}$, the melt cooled to $1200^{\circ} \mathrm{C}$, held at $16 \mathrm{H}$, and furnace cooled

Pseudobrookite $\left(\mathrm{Fe}_{2} \mathrm{TiO}_{5}\right)$ at $1300^{\circ} \mathrm{C}$, zirconolite at $1250^{\circ} \mathrm{C}$ and at $\sim 1200^{\circ} \mathrm{C}$, augite $\left[\mathrm{Ca}(\mathrm{Mg}, \mathrm{Fe}) \mathrm{Si}(\mathrm{Ti}, \mathrm{Al})_{2} \mathrm{O}_{6}\right]$ below $1150^{\circ} \mathrm{C}$.

Zirconolite is a function of the amount of $\mathrm{TiO}_{2}$ present in the melt.

Leach rate for $237 \mathrm{~Np}$ is typically high relative to the leach rates measured for other actinide elements; zirconolite (white), $\mathrm{Zr}$, Ti, $\mathrm{Ca}, \mathrm{Gd},(\mathrm{U}),(\mathrm{Fe})$; pseudobrookite (grey), Ti, $\mathrm{Fe},(\mathrm{Al}),(\mathrm{Mg}),(\mathrm{Zr})$; glass (background), $\mathrm{Si},(\mathrm{K}),(\mathrm{Fe}),(\mathrm{Al}),(\mathrm{Ti}),(\mathrm{Zr}),(\mathrm{Ca})$ •

Mixed Waste Integrated Program - Plasma Hearth Process Program Review

December 1, 1993

Fixed-hearth plasma has potential to treat $75 \%$ of mixed waste streams; can treat entire drums of waste without opening them; can treat a wide variety of waste streams; adaptable to mixing waste streams; reduces characterization requirements; stable leach-resistant waste form produced with hazardous metals and nuclides bound in slag; high potential to meet RCRA regulations

Most applicable PHP candidate wastes: heterogeneous solids, soils, sludges, combustibles

Least applicable PHP candidate wastes: lead metal; high levels of mercury contamination; high volumes of aqueous wastes; explosives

Proof-of-Principle Testing: treat full-size drums (no pretreatment), wide range of waste streams, destruction of organics, final waste form quality; separation of reduced metal phase

Buried waste forms: soil only, high bulk combustibles; high metals, sludge (2 types, organic and inorganic)

Process throughputs: $210 \mathrm{lb} / \mathrm{hr}$ for high BTU feeds; $560 \mathrm{lb} / \mathrm{hr}$ for low BTU feeds

Average CO levels maintained below $100 \mathrm{ppm} ;<2.5 \%$ carbon in slag; $<2.0 \%$ carbon in flyash

Offgas Analysis: $2 \%$ of feed material mass collected as particulate in the baghouse; stack particulate loading from .001 to $.008 \mathrm{gr} / \mathrm{dscf} ; \mathrm{NO}_{\mathbf{x}}$, $<100 \mathrm{ppm}$ for most runs; some numbers as high as $3,500 \mathrm{ppm}$ 
TCLP Test Results; Product Consistency Test (PCT) Results

Issues to be Addressed: High temperature materials of construction, material handling, separation of reduced metal phase, replacement of torch electrodes, processing efficiency/life cycle cost; secondary waste generation/managment; fate of radionuclides (surrogate basis)

Environmental Performance Evaluation: conformance to RCRA

(DRE/TCLP), volatilization of heavy metals, formation of $\mathrm{NO}_{\mathbf{x}}$, gaseous emissions limits (e.g., particulate), quality of final products

Complete testing program, July 1995

Full scale unit (1-1.5 MW, approximately $1 \mathrm{drum} / \mathrm{hr}$ )

\section{The Plasma Hearth Process for Buried and Stored TRU Waste}

Ray Geimer

Science Applications International Corporation

Drivers for TRU Treatment: Performance assessment, gas generation from untreated waste, scenario for a future intruder; Rigorous characterization will require major expenditures: high temperature melting can reduced characterization costs

Waste Processing Concept: High process temperature destroys organic materials; Melts remaining inerts and bulk metals; Inerts and oxidized metals form slag; Slag forms high integrity final waste form, can use additives to optimize properties; Radionuclides and heavy metals captured in slag (reduced leachability)

\section{Fixed Hearth Plasma Process Engineering Design Considerations} James A. Batdorf, Ph.D

Science Applications International Corporation, July 29, 1992

Supercompacted 35-gallon steel drums; Composition ranging from $100 \%$ metal to $20 \%$ metal and $80 \%$ combustible

Treat Objectives: Gasification of the organic fraction; Melting of the metal and inert fraction; Separate the molten material into a metal and a slag phase; offgas; Cool offgas and remove particulate; Solidify the molten phases

Primary Chamber; Secondary Combustion Chamber; Offgas Treatment System; Offgas Quench; Particulate Removal

\section{Fixed Hearth Plasma Process Results of Current Tests}

James A. Batdorf, Ph.D

Science Applications International Corporation, July 29, 1992

All steel, 200 lbs. per puck, process time 20 minutes per puck; mixed metal, 20 minutes per puck; all combustible, process time 20 to 30 minutes per puck

Offgas Emissions

During Treatment of Combustibles

$\mathrm{CO} \quad 20 \mathrm{ppm}$

NO $\quad 100 \mathrm{ppm}$ to $400 \mathrm{ppm}$

$\mathrm{O}_{2} \quad 11 \%$ to $13 \%$

During Treatment of Mixed Metals

$\mathrm{CO}<10 \mathrm{ppm}$ 


$$
\begin{array}{ll}
\mathrm{NO} & \mathrm{Up} \text { to } 3500 \mathrm{ppm} \\
\mathrm{O}_{2} & \mathrm{Up} \text { to } 18 \%
\end{array}
$$

Process Optimization: Test process design, molten material handling, separation of slag from metal, feed system; Materials of construction; Methods to increase processing rates; Alternative torch gases

Glass chemistry (additives); Glass property test, homogeneity, leachability, permeability, strength, brine tests, homogeneity; Final physical waste forms, molds, pour into final disposal container, marbles

Plutonium Studies: Partitioning studies (melt/offgas), volatilization potential, control and capture; Partitioning studies (metal/glass), is bulk metal LLW, fluxes to induce partitioning, could use plutonium surrogate or actual plutonium; Criticality control, study to determine criticality potential, additives to enhance criticality control (e.g. borosilicate)

Technology Development for Magnetic and Non-Magnetic Melt/Slag Treatment of Mixed Wastes

MWIP Presentation, pp. 1-29, 1993

The Plasma Hearth Process Technology Development Project R. Geimer, J. Batdorf, P. Wolfe

Proceedings of the Second International Symposium on Mixed Waste, Baltimore, MD, August 17-20, 1993, pp. 7.4.1-7.4.8

High temperature vitrification; initial testing completed on several different surrogate waste forms; destruction of organic

Schematic of the PHP Test Apparatus; Particulate Emissions Summary;

TCLP Results from Plasma Test Slag Samples; Comparison of Normalized PCT Results Between RFP Plasma Test Glass and Savannah River Glass

\section{The Cold-Crucible Glass Melter}

Claude G. Sombret

Rhone Valley Research Center, May 10-11, 1993

Larger throughput, higher melting temperatures; direct induction, watercooled crucible to melt metal waste; water-cooled sectorized metal crucible instead of the initial hot refractory crucible; allows high-silica glass, eliminates crucible corrosion problems, increases melter capacity

Glass is fully contained in a solid glass "crust"; "skull melting"

Crucible bottom supporting glass casting nozzle; high frequency generator, inductor and trimming capacitors; preheating system required on startup; $0.55 \mathrm{~m}$ in diameter, $0.70 \mathrm{~m}$ high; drain nozzle; air or argon injectors; $240 \mathrm{~kW}$ at $12,000 \mathrm{~V}, 335 \mathrm{kHz}$; null potential between the cold crucible and earth

Preheating System, microwave system, $25 \mathrm{~kW}$ generator, $915 \mathrm{MHz} ; 124 \times 248$ $\mathrm{mm}$; melt $\mathrm{UO}_{2}$ at $2500^{\circ} \mathrm{C} ; 25 \mathrm{~kg} . \mathrm{h}^{-1}$ for the 0.35 m diameter; $50 \mathrm{~kg} . \mathrm{h}^{-1}$ for the $0.55 \mathrm{~m}$ diameter melter; $1300^{\circ} \mathrm{C} ; 1$ meter in diameter, $200 \mathrm{~kg}$ of glass per hour with dry material 
French building a vitrification facility for low-level liquid waste in the Czech Republic; full-scale prototype $0.60 \mathrm{~m}$ in diameter will begin operating at the site in 1994

Cold Crucible Techniques (May 1991)

Report on the STATE OF THE ART in France

Prepared by CEA \& SGN for NUMATEC, Inc.

To reduce the corrosion of the crucible, heat flux not transmitted through the wall of the crucible; wall of the crucible is cooled

1 to $10 \mathrm{kHz}$ metals; 100 to $500 \mathrm{kHz}$ in the case of glass or dielectric materials; crucible non-conductive material or made of narrow and insulated metallic strips; metallic strips are cooled by water with the strips or copper tubes welded outside.

Melting of hulls, 1983. Twenty tons of stainless steel and zircaloy, radioactive stainless steel hulls of breeder fuels in a hot cell; high $\alpha$ decontamination factor; $\alpha$-contamination is essentially dissolved in the flux; large capacity glass melting furnace based on the cold crucible technique; induction plasma torch; crucible is protected from corrosion by a layer of solid material; RF-generator is located in the non-nuclear area; ingots $200 \mathrm{~mm}$ in diameter and $1000 \mathrm{~mm}$ in length; argon atmosphere; bottom is closed by a water-cooled moving plate; flux is apportioned to the hull feed rate; $40 \mathrm{~kg}$ per hour to $100 \mathrm{~kg}$ per hour; stainless steel hulls, 17 tons processed; 3 tons of Zircalloy hulls cast; surface area reduction 200; stainless steel hulls, Phénix fast breeder reactor fuel processed; Zircalloy hulls show a lesser degree of decontamination; flux (oxides and fluorides)

\begin{tabular}{cccc} 
& & \multicolumn{2}{c}{ Decontamination Factor for } \\
& & $\alpha$ & beta-gamma \\
Stainless & $75 / 25-\mathrm{CaF}_{2} / \mathrm{MgF}_{2}$ & $\geq 99.5 \%$ & $\sim 11 \%$
\end{tabular}

Vitrification: Hague and BNEL in the UK; nitrate solution, rotary kiln, dried and calcined; calcinate mixed with a glass frit; induction heated inconel crucibles; cold crucible, larger capacity and higher glass temperatures $\left(1400^{\circ} \mathrm{C}\right.$ and over); a hot spot, microwave beam $(25 \mathrm{~kW}) ; 55 \mathrm{~cm}$ in diameter, $50 \mathrm{~kg}$ of glass per hour; cold crucibles readily dismantled and decontaminated; one meter diameter crucible, 10 to $50 \mathrm{kHz}$

Plasma Torch: two types, arc induced plasma and the inductively coupled plasma; inductively coupled plasma with a quartz nozzle, $60 \mathrm{~kW}$; cold crucible plasma torch

The Development of the Double-Stage Process for High Active Waste Solidification (1993)

A. S. Nikiforov, V. I. Vlasov, V. V. Kushnikov, N. V. Krylova, T. S. Smelova, R. N. Salamatina, A. A. Bochvar

Phosphate vitrified materials; calcination in "fluid-bed"; induction-high frequency melter, skull type, cold crucible; $1250-1550^{\circ} \mathrm{C}$ 
"Cold crucibles" made of stainless steel, $0.05-0.12 \mathrm{~m}^{2} ; 160 \mathrm{~kW}$ at $1.76 \mathrm{MHz}$ Spray calcinator, $750^{\circ} \mathrm{C}$; "cold crucible" working temperature $900-2300^{\circ} \mathrm{C}$, $\mathrm{kg} / \mathrm{h}, 30$

Scope of Work - Preliminary Hazards Analysis for the Mired Waste Integrated Program, Plasma Arc Incinerator Science Applications International Corporation, February 23, 1993

Vitrification Chemistry and Nuclear Waste

M. J. Plodinec

J. Non-Crystalline Sol. 84 (1986) 206-214

Systems Approach to Nuclear Waste Glass Development

C. M. Jantzen

J. Non-Crystalline Sol. 84 (1986) 215-225

Redox Control of Electric Melters with Complex Feed Compositions, I. Analytical Methods and Models

D. F. Bickford, R. B. Diemer, Jr.

J. Non-Crystalline Sol. 84 (1986) 276-284

Redox Control of Electric Melters with Complex Feed Compositions, II. Preliminary LImits for Radioactive Waste Melters

D. F. Bickford, R. B. Diemer, Jr., D. C. Iverson

J. Non-Crystalline Sol. 84 (1986) 285-291

Control of Radioactive Wast e Glass Melters

Part I-Preliminary General Limits at Savannah River

D. F. Bickford, A. Applewhite-Ramsey, C. M. Jantzen, K. G. Brown

J. American Ceramic Society 73 (10) 2896-2902 (1990)

Control of Radioactive Wast e Glass Melters

Part II-Residence Time and Melt Rate Limitations

D. F. Bickford, P. Hrma, B. W. Bowan II

J. American Ceramic Society 73 (10) 2903-2915 (1990)

Control of Radioactive Waste Glass Melters

Part III-Glass Electrical Stability

D. F. Bickford, R. C. Propst, M. J. Plodinec

Advances in the Fusion of Glass (Am. Cer. Soc. 1988) 19.1-19.17

Waste Form Performance Criteria and Testing Methods for Mixed Waste

E. M. Franz (BNL), S. Bates $(I N E L)$, R. Peters (PNL)

MWIP Meeting, Santa Fe, NM, February 25-26, 1993

Relevant WF Characteristics: radionuclide content, structural stability, chemical stability (IAEA - leachability), thermal stability, radiation stability; resistance to biodegradation, gas generation, free liquids, corrosivity, pyrophoricity, chelating and complexing agent effects 
Long-term performance: accelerated testing/modeling temp., surface area to volume ratio, exposure rates, etc., model input data, natural analogs, geochemical models

\section{Long-Term Testing and Performance Assessment Modeling} Mark Fuhrmann

Brookhaven National Laboratory, February 26, 1993

Demonstrate regulatory compliance: DOE Order 5820.2a, EPA, Site WAC, States, Transportation; comparisons among waste forms; information on long-term performance

\section{Preliminary Assessment of Disposal Limits for Vitrified Low-Level} Mixed Wastes in RCRA Landfills

James R. Cook, Dennis F. Bickford

"Ceramics in Waste Management", Ceramic Transactions, American Ceramic Society (1993)

RCRA and low-level radioactive wastes; generic modified RCRA landfill is being evaluated for disposal of both hazardous and mixed radioactive and hazardous wastes; LDR; multiple barriers; preliminary upper limits for both radionuclide and hazardous chemical inventories which could be allowed in the landfill; nineteen hazardous chemicals which are typical of DOE waste streams are considered; preliminary limits recommended

HELP code by the U. S. Army Corps of Engineers; PATHRAE computer code Dose Criteria

\section{Petitions to Delist Hazardous Wastes A Guidance Manual (PB85- 194488)}

The Cadmus Group, Incorporated, Belmont, MA, April 1985

National Technical Information Service (NTIS)

Demonstrate a specific waste from a particular generating facility should not be regulated; show that a waste generated does not meet any of the listing criteria; waste does not exhibit any of the hazardous waste characteristics, does not contain any other toxicants at hazardous levels; step-wise approach to compiling a delisting petition; process descriptions, raw material lists, sampling plans, and test data includes a mock or sample petition

Status of Delisting Petition, Environmental Assessment, and Integrated Demonstration

C. M. Jantzen

Westinghouse Savannah River Company, 1993

Provide model or real Delisting Petition for Listed Sludge Vitrification;

Provide model or real Environmental Assessment for Listed Sludge

Vitrification; Listed sludges for treatability studies

Draft Delisting Petition; Comments received from SAIC and LLNL

"Up-Front" Delisting Petition including a statistical sampling plan; TCLP results; Appendix VIII testing of waste instead of MSDS sheets 
Draft Environmental Assessment for M-Area Listed Sludge Stabilization available; EA covers vitrification and cementation

Leach Rate Studies on Glass Containing Actual Radioactive Waste D. D. Walker, J. R. Wiley, M. D. Dukes, J. H. LeRoy

Nuclear Chemical Waste Mgmt., 3 (1982) 91 -94

Effects of Alpha, Gamma, and Alpha-Recoil Radiation of Borosilicate Glass Containing Savannah River Plant Defense High-Level Nuclear Waste

N. E. Bibler

Science Basis Nuclear Waste Mgmt., Elsevier (1982) pp. 681-685

Prediction of Glass Durability as a Function of Glass Composition and Test Conditions: Thermodynamics and Kinetics

C. M. Jantzen

Advances in the Fusion of Glass, American Ceramic Society (1988) 24.1-24.17

Prediction of Radioactive Waste Glass Durability by the Hydration Thermodynamic Model: Application to Saturated Repository Environments

C. M. Jantzen, W. G. Ramsey

Material Res. Society Symposium Proc., Vol. 176 (1990) 217-227

Prediction of Glass Durability as a Function of Glass Composition and Test Conditions: Thermodynamics and Kinetics

C. M. Jantzen

Proc. First International Conference Advances in the Fusion of Glass

American Ceramic Society (1988) 24.1-24.17

Materials Interactions Relating to Long-Term Geologic Disposal of Nuclear Waste Glass

N. E. Bibler, C. M. Jantzen

Material Res. Society Symposium Proc., Vol. 84 (1987) 47-66

Predicition of Glass Durability as a Function of Environmental

Conditions

C. M. Jantzen

Material Res. Society Symposium Proc., Vol. 125 (1988) 143-159

Prediction of Nuclear Waste Durability for Natural Analogs

C. M. Jantzen

Advances in Ceramics, Vol. 20, American Ceramic Society (1986) 703-712

The Role of Groundwater Oxidation Potential and Radiolysis on

Waste Glass Performance in Crystalline Repository Environments

C. M. Jantzen, N. E. Bibler

Material Res. Society Symposium Proc., Vol. 50 (1985) 119-230 
Nuclear Waste Glass Interfaces after 1 Year Burial in Stripa L. O. Werme, L. L. Hench, A. Lodding Material Res. Society Symposium Proc., Vol. 44 (1985) 37-44

Stability of Radioactive Waste Glasses Assessed from Hydration Thermodynamics

M. J. Plodinec, C. M. Jantzen, G. G. Wicks

Material Res. Society Symposium Proc., Vol. 26 (1984) 755-762

Thermodynamic Model of Natural, Medieval and Nuclear Waste Glass Durability

C. M. Jantzen, M. J. Plodinec

J. Non-Crystalline Solids 67 (1984) 207-223

Thermodynamic Approach to Prediction of Stability of Proposed Radwaste Glasses

M. J. Plodinec, C. M. Jantzen, G. G. Wicks

Advances in Ceramics, Vol. 8, American Ceramic Society (1984) 491-495

West Valley Glass Product Qualification Durability Studies: Effects of Composition, Redox State, Thermal History, and Groundwater M. A. Reimus, G. F. Piepel, G. B. Mellinger, L. R. Bunnell

PNL-6723, Battelle Pacific Northwest Laboratory, 1988

A Study of the Isolation System for Geologic Disposal of Radioactive Wastes

National Academy Press, Washington, DC (1983)

Radioactive Waste Forms for the Future

W. Lutze, R. C. Ewing

North-Holland (1988)

Devitrification Behavior of SRL Defense Waste Glass

D. F. Bickford, C. M. Jantzen

Material Res. Society Symposium Proc., Vol. 26 (1984) 557-566

Time-Temperature Transformation Kinetics of SRL Waste Glass C. M. Jantzen, D. F. Bickford, D. G. Karraker

Advances in Ceramics, Vol. 8, American Ceramic Society (1984) 30-38

Leaching of Devitrified Glass Containing Simulated SRP Waste C. M. Jantzen, D. F. Bickford

Material Res. Society Symposium Proc., Vol. 44 (1985) 135-145 
Reactive Additive Stabilization Process (RASP) for Hazardous and Mixed Waste Vitrification (WSRC-MS-93-118)

C. M. Jantzen, J. B. Pickett, W. Gene Ramsey

Proceedings of the Second International Mixed Waste Symposium, Baltimore, MD, August 17-20, 1993

Nickel plating line (F006) sludges and (2) incinerator wastes; enhance the dissolution and retention of hazardous, mixed, and heavy metal species; lowers melt temperatures, minimizing volatility concerns, maximizes waste loading, minimizes waste disposal volume; soda-limesilica (SLS) and borosilicate glasses; volume reductions of 86 and 94 volume \%

\section{Reactive Additive Stabilization Process (RASP): Vitrification of} Nickel Plating Line Wastes

C. M. Jantzen, J. B. Pickett, H. L. Martin, W. G. Ramsey

Symposium, "Emerging Technologies in Hazardous Waste Management, V", Atlanta, GA, September 27-29, 1993

Plating line (F006) sludges; soda-lime-silica (SLS) and borosilicate glasses passed TCLP, LDR limits, volume reductions of $86-88 \%$

\section{Mixed Waste Integrated Program - Vitrification Samples}

Richard Peters

Battelle, Pacific Northwest Laboratory, January 26, 1993

Surrogate waste and corresponding vitrified products; waste and glass compositions, properties of the glass; fabricated at temperatures over $1300^{\circ} \mathrm{C}$

Reactive Additive Stabilization Process (RASP): Vitrification of Mixed Incinerator Ash and Blowdown

C. M. Jantzen

I\&EC Special Symposium, American Chemical Society, Atlanta, GA, September 27-29, 1993

Soda-lime-silica (SLS) glass waste loadings up to $50 \%$ on a dry weight basis; all formulations with precipitated silica passed TCLP, LDR, volume reductions of $94 \%$

ORNL WETF Simulated Sludge Crucible Studies (WSRC-TR-93-)

M. K. Andrews, C. A. Cicero

Westinghouse Savannah River Company, November 1993

Type and amount of glass forming additive; simulated sludge; pass Product Consistency Test (PCT) and TCLP; 45 or 55 weight percent waste loading

45 wt\% WETF, 28 wt\% Borax, 27 wt\% Diatomaceous Earth

45 wt\% WETF, 30 wt\% Borax, 25 wt\% Diatomaceous Earth

$55 \mathrm{wt} \%$ WETF, $45 \mathrm{wt} \%$ Frit 165

XRD, ICPES, and AA

$\mathrm{Pb}, \mathrm{Ni}, \mathrm{Cr}$, and $\mathrm{Cd}$, no detectable release by $\mathrm{PCT}$

TCLP measured releases less than EPA limits; Ce substituted for the U; Ce releases on TCLP below the detection limit 
Reactive Additive Stabilization Process (RASP) for Vitrification of Hazardous and Mired Waste (WSRC-MS-93-121)

C. M. Jantzen, J. B. Pickett, W. G. Ramsey

Westinghouse Savannah River Company, 1993

Nickel plating line (F006) sludges and incinerator wastes; high surface-area additives enhance the solubility and retention of hazardous, mixed, and heavy metal species in glass; soda-lime-silica, borosililcate glasses Consolidated Incinerator Facility, rotary kiln incinerator Glasses melted at $1150^{\circ}$ and $1300^{\circ} \mathrm{C}$; TCLP M-Area Composite Sludge Analyses; Land Disposal Restriction (LDR) Limits Kiln ash was high in $\mathrm{Ca}$ and $\mathrm{Zn}$; high $\mathrm{Na}_{2} \mathrm{O}$

Glass Formulations and Additives for CIF Blowdown and CIF Blowdown with Bottom Kiln Ash at $1150^{\circ} \mathrm{C}$

Task Plan: Solidification of Consolidated Incinerator Facility (CIF) Wastes into Glass (WSRC-RP-93-448)

C. M. Jantzen

Westinghouse Savannah River Company, 1993

Crucible studies have demonstrated that vitrification is a viable proacess for solidification of CIF blowdown waste and mixtures of CIF blowdown and bottom kiln ash waste

\section{Treatment of Mixed F006 Contaminated Material to Meet the New} EPA Debris Rule at the SRS

J. B. Pickett

Proceedings of the Second International Symposium on Mixed Waste, Baltimore, MD, August 17-20, 1993, pp. 6.3.1-6.3.7

Demonstrated a procedure to clean mixed (radioactive/hazardous) wastes to meet the criteria in the recently promulgated Land Disposal Restrictions

Concurrence from the Environmental Protection Agency, equipment could be flushed in place as an integral part of a wastewater treatment facility; after additional scrubbing and cleaning, the equipment was discarded as a non-hazardous low-level radioactive waste

Treatment and Disposal of a Mixed F006 Plating Line Sludge at the Savannah River Site

J. B. Pickett, J. C. Musall, H. L. Martin

Proceedings of the Second International Symposium on Mixed Waste, Baltimore, MD, August 17-20, 1993, pp. 1.3.1-1.3.9

$2800 \mathrm{~m}^{3}$ of an F006 mixed (radioactive/hazardous) wastewater treatment sludge from electroplating operations; uranium

Life Cycle Cost analysis, treat the waste by a hazardous waste managment sub-contractor, one time campaign; $\$ 40$ million could be saved by this approach, vs. the original plan to construct a permanent SRS treatment facility 
Sub-contractor will treat, stabilize, and place the final wasteform in disposal containers; stabilized waste will be disposed to on-site SRS disposal vaults; required a re-negotiation of a federal facility compliance agreement

Design of a Low-Level Waste Resin Vitrification Facility John D. Sachse, Larry R. Eisenstatt

Ceramic Transactions-Advances in Fusion and Processing of Glass, Vol. 29, 1993, pp. 561.566

Resin vitrification, slurry feed system, melter, glass handling system, off-gas system; reduced waste burial cost that is a result of the reduced volume

Immobilization Process for Incinerator Ash

Ron Nakaoka, Kazuki Morita, J. D. Mackenzie

Ceramic Transactions-Advances in Fusion and Processing of Glass,

Vol. 29, 1993, pp. 553--560

Controlled-Air Incincerator

Toxic Substances Control Act (TSCA), Part B permit, Resource Conservation and Recovery Act (RCRA); transuranic, low-level mixed wastes; immobilization of ashes

Waste Form Requirements/Criteria for Disposal at WIPP; microwave vitrification

Vickers Hardness, density and crystal formation; Toxic Characteristic Leach Procedure; $80 \mathrm{wt} \%$ of the lead vaporized during melting

Property and Process Correlations for Iron-Enriched Basalt Waste Forms (EGG-MS-10657)

J. D. Grandy, T. L. Eddy, G. L. Anderson

Idaho National Engineering Laboratory

Composition, Viscosity, Electrical Conductivity, Corrosion of the Melter Refractory, Recrystallization Conditions

Slag Temperature Versus Flux Addition, Leach Rate Versus Flux Addition, Volume Reduction

Effect of alkali content on devitrification temperature

Slag temperature versus slag composition for different alkali flux additions

Leach rate as a function of alkali oxide wt\%

Leach rate for families of alkali flux additions

Coefficients for the electrical conductivity correlation

Vitreous Immobilization of Hazardous Materials from Electric Components: General Model of Acid Leach Resistance

Dennis F. Bickford

Fusion and Processing of Glass, American Ceramic Society, 1992, pp. 473-484

General model developed for comparing to the relative leach response of regulatory tests; sequential calculation of the chemical activity of compounds in the melt, and statistical fitting of the resulting compounds with the corresponding experimental leaching results 
Calcia-Alumina-Silicate Penberthy Glasses for the Immobilization of SRP Waste (DPST-81-699)

P. D. Soper, W. N. Rankin

Savannah River Technology Center, 1981

Conclude that problems presented by melter operation at the very high temperatures required are too severe, and the gain in durability-too small, to justify investigating these compositions further

Corrosive rates of molybdenum electrodes in these CAS glasses for high level waste at $1380^{\circ} \mathrm{C}$ are 8-17 times that of Inconel 690 in borosilicate glass at $1150^{\circ} \mathrm{C}$; volatility increases at least 3-6 times; chemical durability is only slightly improved, at most approximately 4 times; canister filling will be difficult

In-Situ Vitrification of Soil from the Savannah River Site (PNL-7421) B. E. Campbell, J. L. Buelt

Battelle Pacific Northwest Laboratory, August 1990

Savannah River Site soils (clay, sand, and clay/sand mixture) require mixing of a flux to permit vitrification

\section{Offgas Treatment Technical Specification Group}

Nina Bergan French

Santa Fe, NM, February 25, 1993

"Typical" DOE treatment needs

Evaluate 11 "typical" DOE APC systems

Needs: Develop continuous emissions monitors; Extend life of HEPA filters;

Characterize "new commercial technologies; Demonstrate APC performance; Model metals partitioning; Determine radionuclide surrogates; High temperatue particulate removal; Need "state-of-theart" in: Nox abatement, Second-stage destruction technologies/hardware; Minimize secondary waste

A Review of Potential Alternatives for Air Cleaning at the Hanford Waste Vitrification Plant (PNL-7391)

G. A. Sehmel

Battelle Pacific Northwest Laboratory, July 1990

Integrated DWPF Melter System Campaign Report Coupled Feed Operation (WSRC-TR-90-131)

J. A. Ritter, N. D. Hutson, M. E. Smith, M. K. Andrews, D. H. Miller, Jr.

Westinghouse Savannah River Company, March 1, 1990

Development of Modeling Tools for Design of Clemson Vitrification Facility Wet Off-Gas System (NES-CDG-930128)

A. L. Kielpinski

Westinghouse Savannah River Company, June 3, 1993

Design of the wet off-gas system, modeling tools, guide sizing decisions and predict system performance; pressure drop and velocity; performance models for the particulate and acid removal capabilities of system components 
Design Criteria; Pressure Drop Calculation; Performance Calculation for Venturi Scrubber; Performance Calculation for Nox Packed Column Absorber

Relationship Between Borosilicate Glass Composition, Structure, and Durability Test Response (WSRC-MS-92-485)

W. G. Ramsey, C. M. Jantzen, T. D. Taylor

Westinghouse Savannah River Company, 1992

Chemical durability 30 glasses from the $\mathrm{Na}_{2} \mathrm{O}_{2} \mathrm{~B}_{2} \mathrm{O}_{3} \cdot \mathrm{SiO}_{2} \cdot \mathrm{Al}_{2} \mathrm{O}_{3} \cdot \mathrm{Fe}_{2} \mathrm{O}_{3} \cdot \mathrm{CaO}$ system; two standard leach tests, MCC-IP and PCT

\section{Canonical Correlation of Waste Glass Compositions and Durability,} Including pH

Dolun Oksoy, W. Gene Ramsey, Dennis F. Bickford, L. David Pye, C. M.

Jantzen, T. D. Taylor

Amercian Ceramic Society Annual Conference, Cincinnati, OH, April, 1993

Seven day PCT leach test were analyzed using canonical correlation methods; inclusion of the $\mathrm{pH}$ term leads to an extremely high correlation coefficient of $R=-0.984$; leachate final $\mathrm{pH}$ could be predicted by $\mathrm{R}$ of 0.952

Measurement of Cesium Emissions During the Vitrification of Simulated High Level Radioactive Waste (WSRC-MS-92-251)

John R. Zamecnik, Donald H. Miller, Joe T. Carter

ICP-MS measures cesium as low as $0.135 \mu \mathrm{g}$

Design and measured cesium decontamination factors

Table 3. Design and measured cesium decontamination factors. 5

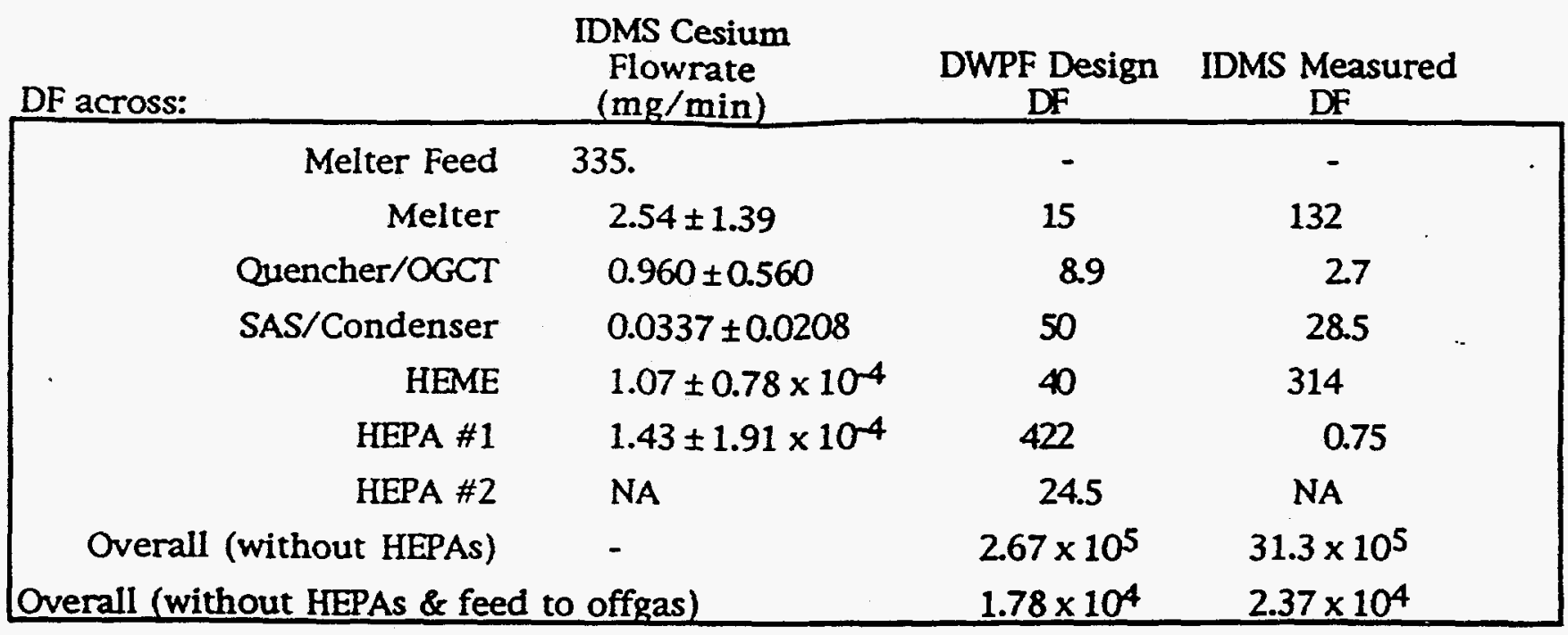


Development of Mixed Waste Vitrification Flowsheet Using ASPEN+ Simulator, SRT-GTC-83-0101

A. L. Kielpinski

Savannah River Technology Center, November 23, 1993

ASPEN + is a steady-state process simulator for chemical industry; modeling tool of choice by Mixed Waste Integrated Program; documents initial development of a flowsheet for vitrification systems; simulates melter plus offgas system, report describes the basic modeling approach, model status, and model development action items; presents an example simulation; ASPEN + has the potential to provide realistic process flowsheet modeling

\section{SRL Incincerator Components Test Facility (DP.1640)}

Eric J. Freed

August 1982

Controlled-air incinerator; ICTF Ash Analysis; Nominal Composition of Combustible TRU Waste; Composition of Common Waste Materials; Physical Properties of ICTF Ash and Slurry; Composition of Individual Waste Component Ash by Spark-Source Mass Spectrometry; Wet Offgas System; Dry Off-gas System; Instrumentation; Burning Rate Studies; Incinerator Controls; Primary and Secondary Vacuum; Secondary Air Flowrate; Primary Air Flowrate; Waste Feedrate; Temperature Control

Particulate Carryover, less than $0.04 \%$ of the feed material; particulate in acid scrubber, carbon and $\mathrm{Fe}, \mathrm{Zn}, \mathrm{Cu}, \mathrm{Ca}, \mathrm{Na}, \mathrm{Cd}, \mathrm{Cr}, \mathrm{Ni}$, and $\mathrm{Pb}$; Decontamination Factor; overall carryover factor $0.26 \%$ Alloys Tested; Corrosion Rates

\section{SRL Mobile Off-Gas Unit HEPA Filter Loading Test Results (WSRC-} RP-89-242)

D. B. Burns

Savannah River Technology Center, April 3, 1989

At low off-gas flows (<50\% of design flow), scrub water was transferred, preventing efficient operation of the 2-loop system

\section{Transuranic Waste Shredding Tests (DPST-88-1041)}

R. S. Simpson

Savannah River Technology Center, March 31, 1989

Drums and angle iron, produced shredded piece sizes too large for packaging in 55-gallon drums; double shredding arrangements produce acceptable piece size; volume reduction averaged about 2:1

High Temperature Materials for Radioactive Waste Incineration and Vitrification

D. F. Bickford, R. S. Ondrejcin, L. Salley

Advances in Ceramics, Vol. 20 (1987) 65-78 
Corrosion Testing of High Chromium Alloys in Simulated Waste Environments (DP-MS-89-17)

R. A. Corbett, D. F. Bickford

Westinghouse Savannah River Company, April 1989

Electrode Corrosion and Ruthenium Behavior in a Small Joule -..Ceramic Melter

J. B. Morris, et al.

Proc. Nuclear and Hazardous Waste Mgmt., Spectrum '86, Am. Nuclear

Society, Niagara Falls, NY (1986) 961-7-971

Material Selection Processes and Case Histories Associated with the Hazardous Industrial and Municipal Waste-Treatment Industries

D. C. Agarwal, F. G. Hodge

Proc. 1st Annual Hazardous Materials Mgmt. Conf., Phil., PA, 1983, 255-259

Synopsis of Materials Analyses of Samples from EnVitCo Melter for M-Area Vitrification Campaign (SRT-MTS-93-4090)

Jim Marra

Savannah River Technology Center, October 28, 1993

Samples following the 5\% anhydrous borax run of the M-area sludge; Molybdenum electrode, glass/refractory interface; drain plug and drain tube, and glass from the solidified melt pool were examined.

No Chemical Attack on the electrodes from species in the melt; shape of the electrodes was due to melting and solidification

Sample near the cooling jacket, some degradation; attributable to some oxidation and volatilization of the Mo in this region

Degradation of the refractory walls a result of excessive temperature adjacent to electrodes

"Droplet from end of drain tube"; $\mathrm{Al}, \mathrm{Mo}, \mathrm{K}$ and possible $\mathrm{S}$ and $\mathrm{Cl}($ ?)

"Corpuscles": XRF, Mo in the "corpuscle", potassium and/or sodium

Extending the Life of a Magnesite-Chrome Submerged Arc Furnace Lining Through Improved Slag Chemistry Control

Richard H. Hanewald, David M. Hoffman (INMETCO®)

J. Roy Gordon (Research Laboratory INCO Limited), Dr. Christopher Doyle

Fused-Cast Magnesite-Chrome Refractory, slag chemistry hs been modified to decrease the corrosiveness

EAF baghouse dust, mill scale and grinding swarf; recovery of nickel, chronium, and iron from hazardous and nonhazardous waste; spent pickling solutions, pickling and wastewater treatment filter cakes, acid scale, carbon brick, spent baghouse bags, torch cutter dust and spent dolomitic- and chromium-bearing refractories

Feed preparation, blending, pelletizing; reduction in a rotary hearth furnace, smelting and casting; 6.2 MVA, three phase, electric arc furnace; $1440^{\circ}$ to $1540^{\circ} \mathrm{C}$ 
Final Examination of IDMS Corrosion Coupons (WSRC-TR-93-461)

K. J. Imrich, C. F. Jenkins

Savannah River Technology Center, September 16, 1993

Corrosion coupons removed from the Integrated DWPF Melter; no corrosive attack or abnormal wear was observed on coupons, IDMS Feed Preparation System, including Hastelloy C-276; exposure represents approximately 4 months of DWPF operation; internal inspection is necessary to fully assess any abrasive damage

All coupons in the Quencher Inlet region of the Off-Gas System exhibited localized corrosion representing four years of DWPF operation; Alloys 690 and Allcorr experienced significant corrosive attack, but not sufficient to affect operating life; C-22 and Inconel ${ }^{\mathrm{TM}} 625$ exhibited superior corrosion resistance and must be considered for the next generation Quencher

Pitting observed in austenitic stainless stell in Off-Gas Condenser vapor inlet and the HEME inlet; Hastelloy C-276 and are not subject to corrosion in this environment

System was started in April 1989; sludge for 16 tests contained reference levels of all materials, including halides and sulfates. Mercury, noble metals, selenium (Se) and tellurium ( $\mathrm{Te}$ ) were added to several of the batches.

The Rate of Formation of SiO by the Reaction of $\mathrm{CO}$ or $\mathrm{H}_{2}$ with Silica and Silicate Slags

B. Ozturk, R. J. Fruehan

Metallurgical Transactions B, Volume 16B, December 1985, pp. 801-806

Rate of formation of $\mathrm{SiO}(\mathrm{g})$ by the reaction of $\mathrm{CO}$ and $\mathrm{H}_{2}$ with silica or silicate slags containing $\mathrm{SiO}_{2}, \mathrm{CaO}$, and $\mathrm{Al}_{2} \mathrm{O}_{3}$ has been measured; the rate with hydrogen is controlled by gas phase mass transport; the rate of formation of $\mathrm{SiO}$ by the reaction of silica with $\mathrm{CO}$, strongly indicate the rate is controlled by chemical kinetics on the surface; similar results were obtained for the rate of reaction of $\mathrm{CO}$ with silica in slags; the rate was found to be proportional to the activity of $\mathrm{SiO}_{2}$ and $\mathrm{CO}$ pressure; has implications for volatility of metals under reducing conditions

\section{Vitrification of Heterogeneous Weapons Components}

Matt Cooper

Pacific Northwest Laboratory

American Ceramic Society Annual Conference, Cincinnati, OH, 1993

Electronic and electromechanical components; lead, cadmium, and chrome, PCBs, asbestos, disassembly and segregation difficult

Prediction of Corrosion Rate of Refractory Walls

Frank E. Woolley, William W. Johnson, James C. Hayes

Proceedings of the 1st International Conference on Advances in the Fusion of Glass, ACS, June 14-17, 1988 
Corrosion rate is determined primarily by temperature of the glass-refractory interface; corrosion rate of commercial glasses follow the Arrhenius relation

Electrical Power Supply \& Controls for a Remotely Operated Glass Melter for Nuclear Waste

A. Q. Haideri

Westinghouse Savannah River Company

IEEE; Melter Vessel; Electrode Power Supply Design; Power Controllers; Ground Test Circuit; Lid Heaters and Controllers

\section{Uranium in Soils Integrated Demonstration Site Characterization} (IS-5099)

D. Baldwin, D. Zamzow, S. J. Bajic, S. Weeks, and A. P. D'Silva M. S. Anderson, R. McIntosh, J. Pfeifle, S. Braymen, M. A. Anderson Ames Laboratory, February 2, 1993

Laser Ablation-Inductively Coupled Plasma-Atomic Emission Spectroscopy "fieldable" system, in-situ, elemental analysis; physical samples are not handled by the operator; mounted in a truck and trailer, trailer contains computational and analytical equipment and required utilities; $100^{\prime}$ umbilical cable to the active ablation cell

Detection thresholds vary; 10 's of ppm range; 14 pico Curies/gram (pCi/g)

\section{Operating Procedures for Rapid Transuranic Monitoring Laboratory} (EGG-WTD-10898)

C. V. McIsaac, C. W. Sill, R. J. Gehrke, E. W. Killian, K. D. Watts, C. R. Amaro

Idaho National Engineering Laboratory, October 1993

Procedures to collect, prepare, and analyze soil, smear, and air filter samples for alpha- and gamma-emitting isotopes; procedures for moving and setting up preparation and analysis trailers; mobile, field-deployable; photon spectrometer; alpha spectrometers; alpha continuous air monitors

Hydro-Sonic Scrubber Vendor Test Results (WSRC-RP-89-243)

D. B. Burns, H. Holmes

Savannah River Technology Center, April 24, 1989

Address concerns for HEPA filter plugging caused by $\mathrm{NaCl}$ carry-over; no significant HEPA plugging at $10 \mathrm{wt} \%$ salt concentrations in both the quench and scrubber recirculation loops; carry-over depends primarily on salt concentration in the scrubber liquid 
WSRC-TR-93-762

\section{Distribution:}

J. A. Wright, DOE-SR, 703-A

E. W. Holtzscheiter, 773-A

E. F. Duhn, 773-A

M. J. Plodinec, 773-A

B. D. Helton, 773-41A

W. L. Tamosaitis, 773-A

W. E. Stevens, 773-A

R. H. Hsu, 773-43A

D. A. Crowley, 704-1T

M. E. Smith, 704-1T

L. F. Landon, 704-T

C. T. Randall, 704-T

C. A. Cicero, 773-41A

C. M. Jantzen, 773-A

W. G. Ramsey, 773-A

R. F. Schumacher, 773-41A

K. J. Imrich, 773-A

D. T. Herman, 773-41A

J. C. Marra, 773-A

A. L. Kielpinski, 773-41A

J. C. Whitehouse, 786-6A

TIM, 703-43A (4)

Records Storage, 773-52A 